\title{
EL DERECHO INTERNACIONAL PRIVADO \\ EN LA ERA POSTCOVID
}

\section{PRIVATE INTERNATONAL LAW IN THE POSTCOVID ERA}

\author{
Miguel-Ángel Michinel Álvarez \\ Catedrático de Derecho internacional privado \\ Universidad de Vigo \\ ORCID ID: 0000-0001-8116-4549
}

Recibido: 17.11.2020 / Aceptado: 04.12.2020

DOI: https://doi.org/10.20318/cdt.2021.5968

Resumen: Ante el retroceso de la globalización, generado por las sucesivas crisis económicas acaecidas a lo largo del presente siglo, culminadas con la actual pandemia mundial causada por la COVID-19, el Derecho internacional privado debe hacer frente a los retos que se plantean en el nuevo escenario donde se han de desarrollar las relaciones transfronterizas, cuyo examen constituye el objeto principal del presente trabajo a partir del estudio de una serie de casos significativos.

Palabras clave: Derecho internacional privado, justicia civil transfronteriza, protección de datos, recursos genéticos, economía de plataformas.

Abstract: Faced with the decline of globalization, generated by the successive economic crises that have occurred throughout this century, culminating in the current COVID-19 global pandemic, private international law must face the challenges that arise in the new scenario where cross-border relations shall develope, being their examination the main object of this work, from the study of a series of significant cases.

Keywords: International private law, crossborder civil justice, data protection, genetic resources, platform economy.

Sumario: I. Introducción. II. Nuevos modelos de persona y de familia en Derecho internacional privado. 1. La "personalidad electrónica". 2. La digitalización y la transparencia de las personas jurídicas. 3. La gestación subrogada transfronteriza. III. La sociedad de la hiperinformación. 1. La transferencia internacional de datos desde la UE. 2. El bloqueo geográfico de interfaces en línea. 3. La gobernanza contractual en las plataformas digitales. IV. La justicia civil transfronteriza lowcost de la UE. 1. La plataforma de la UE para resolución en línea de litigios en materia de consumo. 2. El futuro de las acciones colectivas en la UE. 3. La notificación electrónica. V. Hacia un Derecho internacional privado protector de intereses colectivos. 1. La protección de los bienes culturales. 2. La protección internacional de los recursos genéticos. 3. La protección contra inversiones extranjeras. VI. Conclusiones.

\section{Introducción}

1. En la década de los años sesenta del pasado siglo, debido al gran crecimiento del comercio internacional, se inició un proceso en los mercados financieros -que entonces afectó fundamentalmente al mercado de divisas- que se consolidaría en la década de los setenta, al abrirse a los mercados de ren- 
ta fija (básicamente, deuda pública, obligaciones y bonos). Pero será en la década de los años ochenta cuando por fin alcance a la renta variable ${ }^{1}$, originando así lo que se conocerá como "globalización", consecuencia directa de unas necesidades de financiación de las empresas que difícilmente se colmaban dentro su propio territorio, lo que las conducía a captar recursos en otros mercados. La globalización de los mercados financieros se entendió que suponía tanto ventajas económicas como ventajas políticas. Entre las primeras, básicamente, la posibilidad de buscar y de realizar inversiones en el extranjero, para lo cual era necesaria una apertura de los mercados que garantizase el acceso a los mismos de las inversiones foráneas, eliminando o, al menos, relajando las trabas al libre flujo de los capitales (siendo éste el sentido en que globalización se opone a segmentación de los mercados). Entre las ventajas políticas, se veía una cierta función fiscalizadora sobre el legislador nacional, ya que los errores de regulación del mercado serían penalizados: un mercado excesivamente regulado que impusiera costes no competitivos sobre las transacciones sería evitado; del mismo modo que un mercado infrarregulado resultaría demasiado arriesgado para los inversores foráneos, que renunciarían al mismo².

2. Los atentados contra el World Trade Center de Nueva York, el 11 de septiembre de 2001, marcaron el comienzo del declive en el proceso de globalización descrito, que se había venido asociando con una concepción salvaje del capitalismo, impulsada por Ronald Reagan en los Estados Unidos y por Margaret Thatcher en el Reino Unido, haciendo prevalecer el beneficio de los accionistas ante cualquier toma de decisión empresarial relevante (Shareholder Capitalism). En diciembre de ese mismo año, se produjo la quiebra del gigante energético Enron, primer distribuidor a nivel global, que facturaba cifras del orden de 100.000 millones de dólares anuales. La fecha coincide también con el punto álgido del pinchazo en la burbuja de las empresas punto.com, que se había venido desinflando desde marzo de 2000, provocando unos cinco billones de dólares en pérdidas de valor de las compañías tecnológicas, hasta octubre de 2002. Momento en que comenzó a gestarse la siguiente gran crisis, relacionada con las denominadas hipotecas subprime, entre 2002 y 2006, que estalló en los Estados Unidos en 2007, llevándose por delante a Lehman Brothers, el cuarto banco de inversión más grande de los Estados Unidos, declarado en quiebra el 15 de septiembre de 2008. Como es sabido, la crisis -conocida como la Gran Recesión- no tardó en contagiarse a Europa, en general, y a España, en particular, prolongándose en nuestro país hasta el año 2014, según los datos del $\mathrm{INE}^{3}$, aunque tardaría varios años más en recuperar algunas de sus variables más importantes. Pero, en cualquier caso, apenas un lustro después, el 31 de diciembre de 2019, se reporta a la OMS de Wuhan (China) la existencia de una serie de casos de una neumonía de origen desconocido con el epicentro en un mercado de pescado local. El resto de la historia ha copado los titulares de la prensa internacional a lo largo del año 2020, continuando en el 2021, por lo que es de sobra conocida. Quedan todavía meses de la pandemia que ha asolado al mundo durante el último año, cuyos efectos socioeconómicos posiblemente permanecerán durante mucho más tiempo del deseable. Parece el momento de pasar del Shareholder Capitalism al Stakeholder Capitalism.

3. El panorama que han dejado las sucesivas oleadas de crisis descritas en el párrafo anterior ha dado lugar así, entre otros aspectos relevantes en el ámbito internacional, a un reforzamiento de las fronteras nacionales, a un mayor intervencionismo del Estado en la economía y a una modulación de ese capitalismo salvaje aludido en favor de un modelo más pendiente de los beneficios para todas las partes interesadas sobre la base de los principios del desarrollo sostenible ${ }^{4}$. Todos estos factores influyen en el

${ }^{1}$ Puede verse con más detalle esta evolución en M. OBstfeld, “The Global Capital Market: Benefactor or Menace?”, Journal of Economic Perspectives, 1998, pp. 9-30, pp. 11-12.

${ }^{2}$ Vid. H. BAum, "Globalizing Capital Markets and Posible Regulatory Responses”, en J. BASEDow (Coord.) Legal Aspects of Globalization, La Haya, Kluwer, 2000, pp. 77-132, pp. 79-80, M. OBSTFELd, loc. cit., passim; C. C. von Weizäcker, Logik der Globalisierung, Göttingen, Vandenhoek und Ruprecht, 1999; P. KRUGMan, Der Mithos vom globalen Wirtschaftskrieg, Frankfurt an Main, Campus, 1999.

${ }^{3}$ Vid. https://www.mineco.gob.es/stfls/mineco/prensa/ficheros/noticias/2014/140227_NP_rpCN4T13.pdf

${ }^{4}$ El Stakeholder Capitalism es el mensaje popularizado por Klaus Schwab, cofundāor del Foro Económico Mundial de Davos (Suiza), lanzándolo como forma de "moldear" el capitalismo para hacerlo inclusivo (vid., por todos, R. E. FREEMAN y K. E. MARTIN, “Stakeholder Capitalism”, Journal of Business Ethics, vol. 74/4, 9/2007, pp. 303-314). 
comercio internacional donde, además, cuestiones clave, como el complejo equilibrio entre la protección de datos y la transparencia, la evolución exponencial de la economía de plataformas y la necesidad de articular vías más rápidas y asequibles para la resolución de conflictos, abren nuevos frentes de problemas en el entorno transfronterizo, a los que el Derecho internacional privado (particularmente, desde la UE) debe ofrecer una respuesta adecuada. Pero también otros sectores habitualmente menos susceptibles de ofrecer novedades de gran calibre en nuestra disciplina, como puede ser en el ámbito del Derecho de la persona o el de la familia, están experimentando un giro radical en sus paradigmas de una forma que hubiera sido insospechada siquiera a inicios del presente siglo. Para abordar el análisis de la situación actual, cabe recordar que los fenómenos cotidianos pueden acceder al plano eidético mediante una hermenéutica que asuma el dinamismo jurídico, en la línea de pensamiento iniciada a principios del siglo XX por ADOLF ReINACh, discípulo de EDMund Husserl, dando paso al análisis fenomenológico en el terreno del Derecho privado 5 . Así, la intención del presente trabajo es reportar un catálogo de supuestos con suficientes cantidad y variedad de la que se pueda inducir el sentido del Derecho internacional privado a las puertas de la nueva década. Aun reconociendo que la novedad absoluta en la investigación jurídica es difícil de alcanzar ${ }^{6}$, ciertamente, en palabras del prócer cubano José MARTí, "todo está dicho ya; pero las cosas, cuando son sinceras, son nuevas". De ahí que una perspectiva como la presente, en tanto se considere honesta, pueda aparecer también como novedosa. La exposición de los distintos problemas se dividirá en cuatro bloques, a saber: los nuevos modelos de persona y familia; la sociedad de la (hiper)información; la implementación en la UE de una justicia civil ${ }^{7}$ transfronteriza low cost; y lo que se podría denominar un Derecho internacional privado "híbrido", para la protección de concretos intereses colectivos.

4. El primer bloque anunciado se refiere a cuestiones propias del Derecho de la persona y de la familia, abordando desde una perspectiva transfronteriza los nuevos modelos surgidos en ambos sectores. Así, en primer lugar, se presenta la controvertida idea de una categoría diferenciada, además de la correspondiente a la persona física y la persona jurídica, bajo la posible denominación de "persona electrónica", en el entorno de los problemas legales que genera la existencia de robots y el uso de mecanismos de inteligencia artificial (el "Internet de las cosas"); en segundo lugar, dentro de este núcleo de cuestiones que atañen a la persona, se incluye asimismo la nueva regulación europea que concierne a la digitalización y transparencia de las sociedades; y, para finalizar este primer conjunto de situaciones, se analiza, en el ámbito del Derecho de familia, el fenómeno de la denominada "gestación subrogada" o "por sustitución" en su dimensión transfronteriza. El segundo bloque de asuntos alude a la denominada "sociedad de la información", caracterizada en el momento presente por el exceso y la hipertrofia, aspecto que engloba tres cuestiones diferentes: en primer lugar, los problemas que plantea la protección de datos personales, desde el punto de vista de la regulación que precisa su transferencia internacional; a continuación, se trata la situación abierta en el ámbito del derecho del consumo ante el bloqueo geográfico a determinados servicios en Internet; y se termina este conjunto analizando las posibilidades de gobernanza en las plataformas digitales, a través de mecanismos de participación ciudadana. El tercer bloque versa sobre asuntos relativos al Derecho procesal civil internacional, bajo la denominación genérica de "justicia civil transfronteriza low cost en la UE", donde se exponen las nuevas soluciones que intentan agilizar, facilitar y abaratar la tutela judicial civil efectiva, particularmente, de consumidores y usuarios. En el mismo, se exponen nuevas fórmulas surgidas a este respecto, como la plataforma de la UE para la resolución online de conflictos en materia de consumo; el futuro de las acciones colectivas transfronterizas, como

5 "Die Erforschung der ewigen Seinsgesetze welche in den reinen rechtlichen Gründbegriffen gründen" [Zur Phänomenologie des Rechts. Die apriorischen Grundlagen des bürgerlichen Rechts, Kössel Verlag, Müchen, 1953 (original de 1913), p. 164].

${ }^{6}$ Algunas cuestiones que serán expuestas fueron ya avanzadas en su día, por F. GARAU Sobrino, "El Derecho internacional privado que viene: el futuro ya está aquí”, Anuario Español de Derecho internacional privado, t. XVII, 2017, pp. 303-332; id., “¿Qué Derecho internacional privado queremos para el siglo XXI?”, Cuadernos de Derecho Transnacional, octubre de 2012, vol. $4 / 2$, pp. 140-158.

${ }^{7}$ Se adopta aquí la denominación "justicia civil", frente a otras posibles, por encontrarla más ajustada a las particularidades que reviste la prestación de la tutela judicial efectiva en el Derecho procesal civil internacional actual, particularmente, en la UE (al igual que hace C. Otero GarCíA-CASTRILlón, Justicia civil en la Unión Europea: evaluación de la experiencia española y perspectivas de futuro, Madrid, Dykinson, 2017, passim). 
vía idónea para la tramitación de los hiperprocedimientos multitudinarios que nacen a consecuencia de la masificación de las relaciones comerciales; y se concluye con la situación actual y el futuro inmediato de la administración electrónica, aplicada a la cooperación judicial en asuntos civiles. Finalmente, el último capítulo se dedica básicamente a problemas a caballo entre el Derecho internacional privado y el público -de ahí el calificativo empleado de "híbrido"- centrado en la protección de una serie de intereses colectivos reflejo también de los tiempos que vivimos: los relativos a los bienes culturales, a los recursos genéticos y a las inversiones extranjeras.

\section{Nuevos modelos de persona y de familia en Derecho internacional privado}

\section{La "personalidad electrónica"}

5. El término "inteligencia artificial" (IA) fue acuñado con motivo de una conferencia de verano celebrada en Darmouth (USA) en $1955^{8}$, definiéndose entonces como "la ciencia y la ingeniería de fabricar máquinas inteligentes, en especial programas inteligentes de computación" (entendiendo por "inteligente" la parte de la informática orientada a obtener resultados). Desde entonces, hemos asistido a una evolución tecnológica exponencial en este sector, particularmente, desde los albores del presente siglo, pasando así por diversas fases, desde la conexión a Internet de las personas hasta llegar al actual "Internet de las cosas"; aunque no siempre el desarrollo tecnológico haya ido acompañado del correspondiente y deseable en el plano legislativo, dado que la robótica avanza problemas a los que las normas no siempre dan respuesta adecuada ${ }^{9}$. Conscientes de esta situación, en el marco de la UE han encontrado impulso una serie de iniciativas tendentes a "adoptar un planteamiento coordinado que le permita aprovechar al máximo las oportunidades que brinda la IA y abordar los nuevos retos que conlleva"10. Por lo que se refiere al ámbito jurídico, destacan especialmente dos: el Informe de la Comisión de Asuntos Jurídicos con recomendaciones destinadas a la Comisión sobre normas de Derecho civil sobre robóti$\mathrm{ca}^{11}$; y la Resolución del Parlamento Europeo sobre una política industrial global europea en materia de inteligencia artificial y robótica ${ }^{12}$. Dejando aparte los compromisos éticos y políticos generales que ambos textos recogen y centrándonos en el ámbito del Derecho privado, aunque el panorama abarca un conjunto amplio de problemas, ciertamente destaca el relativo al que plantea la responsabilidad por daños a terceros, junto al cual se sitúan, en ocasiones por conexión con el mismo, cuestiones relativas a propiedad intelectual, protección de datos personales o seguros, aunque sin descartar otros sectores, como la responsabilidad contractual ${ }^{13} \mathrm{o}$, incluso, la eventual atribución de una "personalidad electró-

8 J. McCarthy, M. L. Minsky, N. Rochester y C. Shannon, "A Proposal for the Dartmouth Summer Conference on Artificial Intelligence", Conference Announcement, 31 August de 1955 (disponible en http://stanford.io/1bqrAR1). Ciertamente existe una amplia variedad de definiciones y de conceptos a manejar, muchos de ellos todavía controvertidos. Habida cuenta de las limitaciones de espacio que impiden profundizar en estos aspectos terminológicos, aquí se utilizarán "robótica" e "inteligencia artificial" como fungibles, aun siendo conscientes de los diferentes matices entre una y otra noción (vid., por ejemplo, las aclaraciones a este respecto de S. NAVAS NAVARRO, "Smart robots y otras máquinas inteligentes en nuestra vida cotidiana", Revista CESCO de Derecho de Consumo, n 20, 2016, pp. 82-109, pp. 86-91.

${ }^{9}$ M. J. Santos González, "Regulación legal de la robótica y la inteligencia artificial: retos de futuro", Revista Jurídica de la Universidad de León, $\mathrm{n}^{\circ}$ 4, 2017, pp. 25-50, p. 27, cita varios ejemplos.

${ }^{10}$ Inteligencia artificial para Europa, COM(2018) 237 final, Bruselas, 25 de abril de 2018 (Comunicación de la Comisión al Parlamento Europeo, al Consejo europeo, al Consejo, al Comité Económico y Social Europeo y al Comité de las Regiones).

${ }^{11}$ Doc.A8-0005/2017,de27deenerode2017(disponibleenhttps://www.europarl.europa.eu/doceo/document/A-8-2017-0005_ ES.html).

${ }^{12}$ Doc. P8-TA(2019)0081, de 12 de febrero de 2019, (disponible en https://www.europarl.europa.eu/doceo/document/TA8-2019-0081_ES.html).

${ }^{13}$ F. GarAu Sobrino, "El Derecho internacional privado...", loc. cit., pp. 305-310, trata de manera diferenciada respecto de los problemas generales de la inteligencia artificial un supuesto como el de los denominados "smart contracts" que, no obstante, podría ser incluido dentro de aquéllos si se maneja un concepto más amplio de IA, estableciendo un conjunto de casos que abarque no solo las máquinas, sino también "una abanico de supuestos cuyo denominador común es el tratarse de algoritmos, que se escriben en código binario, y que pueden responder a una finalidad prediseñada", como sucede precisamente con los contratos inteligentes (S. NAVAS NAVARro, loc. cit., p. 87). 
nica", como nueva figura diferenciada de las personas físicas y jurídicas, dadas las peculiaridades del nuevo fenómeno ${ }^{14}$. De este modo, en el punto 59 f) del Informe de la Comisión de Asuntos Jurídicos se defiende "crear a largo plazo una personalidad jurídica específica para los robots, de forma que como mínimo los robots autónomos más complejos puedan ser considerados personas electrónicas responsables de reparar los daños que puedan causar, y posiblemente aplicar la personalidad electrónica a aquellos supuestos en los que los robots tomen decisiones autónomas inteligentes o interactúen con terceros de forma independiente". En todo caso, ciertamente, los aspectos civiles presentes en la regulación de la inteligencia artificial abren la puerta al empleo de los mecanismos propios del Derecho internacional privado en asuntos con proyección transfronteriza en este ámbito.

6. Habida cuenta de que el análisis de cada problema, a los efectos de este trabajo, será necesariamente sintético, cabe detenerse aquí en dos apuntes extraídos del citado Informe de la Comisión de Asuntos Jurídicos. En primer lugar, "subraya que un enfoque a escala de la Unión puede facilitar el desarrollo, evitando la fragmentación del mercado interior, y pone de relieve, al mismo tiempo, la importancia del principio de reconocimiento mutuo en el uso transfronterizo de robots y sistemas robóticos; recuerda que la realización de ensayos, la certificación y la autorización de comercialización deberían exigirse solo en un Estado miembro; destaca que este enfoque debería complementarse con una vigilancia de mercado eficaz" ${ }^{15}$. En segundo lugar, "constata que no es necesario modificar de forma sustantiva y con carácter de urgencia las actuales normas de Derecho internacional privado en materia de accidentes de tráfico aplicables en la Unión para adaptarlas al desarrollo de los vehículos autónomos, si bien considera que la simplificación del actual sistema dual con el que se determina la legislación aplicable (basado en el Reglamento (CE) n. ${ }^{\circ} 864 / 2007$ del Parlamento Europeo y del Consejo y el Convenio de La Haya de 4 de mayo de 1971 sobre la ley aplicable en materia de accidentes de circulación por carretera) podría mejorar la seguridad jurídica y limitar las posibilidades de búsqueda del foro más favorable"16. Estos dos vectores pueden servir de base para una sucinta aproximación desde la perspectiva del Derecho internacional privado a los problemas transfronterizos de la IA. El primero, pone de relieve la dialéctica entre el país de origen y el país de destino, trasladable al ámbito de la responsabilidad extracontractual, reflejando una tensión que, desde la óptica del legislador comunitario, a los efectos del mercado interior y del reconocimiento mutuo, tiende a hacer prevalecer la opción por el primero en detrimento del segundo. El otro apunte refleja la necesidad de simplificar el sistema. En este sentido, la propuesta de un "estatuto personal electrónico" puede no resultar disparatada si, como sucede por ejemplo con las personas jurídicas, el ámbito de aplicación de ley rectora fuese lo suficientemente amplio como para permitir la sujeción de un conjunto de cuestiones a un mismo ordenamiento. Aquí, soluciones basadas en el país de origen se han barajado en ámbitos de particular complejidad, como la propiedad intelectual. Un "país de origen" del robot (a modo de "nacionalidad" del mismo) podría cobrar así especial protagonismo en este sector, al menos en el mercado interno europeo. Fuera del mismo, el juego de la cláusula de orden público permitiría corregir eventuales disfunciones del sistema, previniendo así la aparición de eventuales "paraísos robóticos"17.

\footnotetext{
${ }^{14}$ Vid., las consideraciones a este respecto de M. J. SANTOS GonZÁLEZ, loc. cit., pp. 40-46, que se muestra más bien partidaria de esta opción; en contra, en su momento, parece S. NAVAS NAVArro, loc. cit., pp. 93-94.

${ }^{15}$ Doc. A8-0005/2017, cit., "Principios generales relativos al desarrollo de la robótica y la inteligencia artificial para uso civil", ap. 4.

${ }^{16}$ Doc. A8-0005/2017, cit., “Aspectos internacionales”, ap. 60.

${ }^{17}$ Recientemente, A. Bradford, The Brussels Effect: How the European Union Rules the World, Oxford, Oxford University Press, 2020, ha avanzado una teoría según la cual la UE ha llegado a ser el regulador global hegemónico, disfrutando de una suerte de poder silencioso y estratégico (denominado por la autora "efecto Bruselas") que fuerza a las grandes empresas mutinacionales -ávidas de hacerse un hueco en un mercado tan suculento por numeroso y por elevada renta per cápita como el europeo- a ajustarse voluntariamente a los estándares legales de la UE, en diversos ámbitos, de modo que la "race to the bottom" se sustituye por una "race to the top", situación que, en términos de una dinámica que favoreciese las conexiones con el país de origen, podría reducir algunas de las objeciones típicas tradicionalmente asociadas a dicha solución, como la apuntada en el texto.
} 


\section{La digitalización y la transparencia de las personas jurídicas}

7. El acceso a las nuevas herramientas digitales refuerza el proceso de integración del mercado común europeo, extendiéndose también a las compañías de la UE, donde esta tendencia cumple dos objetivos fundamentales ${ }^{18}$. En primer lugar, la puesta en marcha de la actividad económica se agiliza, lo que cobra especial importancia en las relaciones transfronterizas. En segundo lugar, la información relevante para las sociedades ve incrementada su circulación entre los EE.MM., reforzando así la transparencia y, por tanto, la confianza de los operadores, al garantizar un nivel homogéneo de control en toda la U.E., frente a determinados riesgos, como las prácticas abusivas, fraudulentas o interesadas. De ahí que se haya planteado examinar la interrelación entre el empleo herramientas digitales y la transparencia de la actividad de las sociedades en sus actuaciones transfronterizas ${ }^{19}$. Todo ello, finalmente, va a repercutir de forma positiva en la libertad de establecimiento que dispone el artículo 49 TFUE. Tras fracasar el proyecto de Societas Unius Personae (SUP) -primero en favorecer la constitución y gestión de sociedades íntegramente por vía electrónica- ${ }^{20}$, llega la Directiva 2019/1151 del Parlamento Europeo y del Consejo de 20 de junio de 2019, por la que se modifica la Directiva (UE) 2017/1132, en lo que respecta a la utilización de herramientas y procesos digitales en el ámbito del Derecho de sociedades, dentro del llamado Company Law Package, conjunto de medidas propuesto por la Comisión Europea en abril de 2018, que también inclúa las modificaciones estructurales transfronterizas ${ }^{21}$. La Directiva 2019/1151 reforma la 2017/1132, codificando las existentes en materia de Derecho europeo de sociedades y fijando estándares comunes en: a) identificación y acceso a información societaria en plataformas electrónicas; b) constitución en línea de sociedades; c) registro en línea y cierre de sucursales; d) publicidad registral. El plazo de transposición de esta norma al ordenamiento español concluye el 21 de agosto de 2021 y a ello cabe unir que el 10 de junio de 2019 finalizó el plazo de transposición de la Directiva (UE) 2017/828 del Parlamento Europeo y del Consejo, de 17 de mayo de 2017, por la que se modifica la Directiva 2007/36/CE, en lo que respecta al fomento de la implicación a largo plazo de los accionistas ${ }^{22}$, donde se incluye tanto la cadena de transmisión del derecho de voto como el empleo de medios electrónicos en el asesoramiento a sociedades que prestan los proxy advisors.

8. En el contexto expuesto, siguiendo la estructura de la normativa apuntada, cabe examinar los procesos de transparencia y digitalización en materia de sociedades desde la perspectiva tanto de las sociedades cerradas como de las cotizadas. Desde la primera, los aspectos que recoge la Directiva 2019/1151 en materia de digitalización pueden abordarse, por un lado, en relación con la constitución de sociedades y sucursales por medios telemáticos, donde la Directiva exige que el proceso pueda com-

\footnotetext{
${ }^{18}$ D. Zetzsche, “Corporate Technologies - Zur Digitalisierung im Aktienrecht”, Aktien Gesellschaft, no 1-2, 2019, pp. 1-17.

${ }^{19}$ L. Fernández del Pozo y F. Vicent Chuliá, “Internet y Derecho de sociedades. Una primera aproximación”, Revista de Derecho Mercantil, nº 237, 2000, pp. 915-1002.

${ }^{20}$ G. Esteban Velasco, "La Propuesta de Directiva sobre la Societas Unius Personae (SUP): el nuevo texto del Consejo de 28 de mayo de 2015", Anales de la Academia Matritense del Notariado, n 55, 2015, pp. 105-164; C. TeichmanN y A. FrÖLICH, "Societas Unius Personae (SUP): Facilitating Cross-Border Establishment", Maastricht Journal of European \& Comparativa Law, $\mathrm{n}^{\circ}$ 3, 2014, pp. 536-544; M.P. Weller y J. BAUER, "Europäisches Konzernrecht: vom Gläubigerschutz zur Konzernleitungsbefugnis via Societas Unius Personae", Zeitschrift für Europäisches Prozessrecht, $\mathrm{n}^{\circ}$ 1, 2015, pp. 6-31. Más recientemente, L. A. Velasco San Pedro, "De la societas privata europaea a la societas unius personae en las propuestas europeas", Cuadernos de Derecho Transnacional, $\mathrm{n}^{\mathrm{o}}$ 1, 2017, pp. 327-341.

${ }^{21}$ C. Teichmann, "The Company Law Package - Content and State of Play", European Company and Financial Law Review, 1-2, 2019, pp. 3-14; M. Fuentes NAharro, "Hacia la mejora del Derecho de Sociedades de la Unión Europea en materia de digitalización de la vida societaria y de facilitación de operaciones transfronterizas", Revista de Derecho Bancario y Bursátil, $\mathrm{n}^{\circ}$ 150, 2018, pp. 275-276.

${ }^{22}$ Pendiente de aprobación, al momento de redactar estas líneas, el Proyecto de Ley por la que se modifica el texto refundido de la Ley de Sociedades de Capital, aprobado por el Real Decreto Legislativo 1/2010, de 2 de julio, y otras normas financieras, en lo que respecta al fomento de la implicación a largo plazo de los accionistas en las sociedades cotizadas, presentado el 7 de septiembre (disponible en http://www.congreso.es/public_oficiales/L14/CONG/BOCG/A/BOCG-14-A-28-1.PDF), por el que se traspone la Directiva 2017/828. Tanto ella como la norma española de transposición se ocupan de las deficiencias de transparencia ocasionadas por la intervención de intermediarios que se sirven de medios electrónicos para realizar su actividad. La Comisión Europea había remitido el pasado 2 de julio una notificación al Gobierno español pidiéndole explicaciones por el retraso en la transposición.
} 
pletarse íntegramente en línea, suprimiendo así cualquier trámite que suponga una presencia física ${ }^{23}$, excepto la intervención notarial ${ }^{24}$. Aquí, la norma permite también examinar la relación entre la autonomía de la voluntad reflejada en los estatutos y el control de legalidad en la constitución; así como la función que corresponde a las sucursales dentro de las actividades transfronterizas de la empresa ${ }^{25}$. Por otro lado, cabe mencionar asimismo la interconexión entre registros, en especial, por lo que se concierne a la inhabilitación de los administradores: cuando la Directiva obliga a que todos los EE.MM. adopten disposiciones sobre inhabilitación, está armonizando indirectamente, de forma sustantiva y parcial ${ }^{26}$; además, la ausencia de un principio sobre reconocimiento de causas de inhabilitación provoca que éstas queden limitadas con un alcance puramente interno, pese a permitir que los EE.MM. reconozcan como causa de inhabilitación la producida en otro E.M., en sociedades constituidas según su legislación (art. 13 decies 2.II Directiva 2017/1132). Finalmente, la Directiva anima a que los EE.MM. establezcan controles de diferente carácter en el sector de la prevención y abuso del fraude, autorizando la extensión del procedimiento de constitución y registro en casos de sospecha (arts. 13 ter y decies Directiva $2017 / 1132$, versión reformada) ${ }^{27}$. Por su parte, desde la perspectiva de las sociedades cotizadas, cabe considerar la Directiva (UE) 2017/828, relativa al fomento de la implicación de los accionistas. En relación con la misma, destaca el asunto relativo a la información y transmisión del derecho de voto, en concreto, a la falta de transparencia en la cadena de intermediarios; donde es posible referirse tanto a la identificación del accionista -incluyendo beneficiarios- como a la transmisión de información sobre el ejercicio de derechos entre intermediarios financieros para facilitar el ejercicio de los derechos del socio y combatir la discriminación en el precio del servicio de custodia transfronterizo, mediante herramientas electrónicas ${ }^{28}$. En segundo lugar, no se pueden olvidar los problemas que plantea el voto robotizado, puesto que las guías de los asesores pueden contener indicaciones sobre el sentido recomendado del voto en relación con distintos puntos del orden del día ${ }^{29}$; es en este marco donde la posibilidad de un voto

${ }^{23}$ S. Álvarez Royo-Villanova, "Proposal Regarding the Use of Digital Tools and Processes in Company Law: The Practioner's Perspective", European Company and Financial Law Review, n 1-2, 2019, pp. 149-18; algo que ya se contempla de forma generalizada en el caso español (F. J. Alonso Espinosa, "Telemática y derecho de sociedades”, Diario La Ley, no 7800, 2012).

${ }^{24}$ La Directiva permite a los EE.MM. donde intervenga un notario para la constitución mantener ese sistema, siempre que el trámite se realice por vía digital (art. 13 octies de la Directiva 2017/1132, versión reformada por la Directiva 2019/1151).

${ }^{25}$ El cauce más escogido para seleccionar la lex societatis de un E.M. distinto al de la sede real suele ser la sucursal: SSTJUE 9 marzo 199, Centros, 212/7; 5 noviembre 2002, Überseering, 208/00; y 30 septiembre 2003, Inspire Art, $167 / 01$. Asimismo, R. Arenas García, Registro Mercantil y Derecho del comercio internacional, Centro de Estudios Registrales, 2000, pp 113 y ss; J. A. Rueda MARTínez, La sucursal: algunos aspectos de su régimen jurídico, Barcelona, Bosch, 1990. Fuera de España, vid. W. Schön, "The Free Choice between the Right to Establish a Branch and to Set-up a Subsidiary - A Principle of European Business Law”, European Business Organization Law Review, n² 2, 2001, pp. 339-364.

${ }^{26}$ Sobre estas cuestiones, J. C. PAz-Ares Rodríguez, "Minima de malis eligenda": cinco tesis sobre el artículo 213.1 de la Ley de Sociedades de Capital, Revista de Derecho Mercantil, 310, 2018, p. 2 y ss.; E. M. Beltrán Sánchez, "Disposición final vigésima. Reforma de la Ley de Sociedades Anónimas”, en A. Rojo Fernández-Río y A. Beltrán SÁnchez (Dirs.) y A.B. CAMpuzano Laguillo (Coord.), Comentario de la Ley concursal, t. II, Madrid, Civitas, 2004, pp. 3240-3257; J. A. García-CruCES GonzÁlez, La calificación del concurso, Cizur Menor (Navarra), Aranzadi, 2004, pp. 116 y ss; N. FernÁndez Pérez, "La inhabilitación de las personas afectadas por la calificación de los supuestos de concurso de sociedades mercantiles", en AA.VV., Gobierno corporativo y crisis empresariales, Madrid, Marcial Pons, 2006, pp. 457-489; A. ArRIBAs Hernández, "La responsabilidad de los administradores sociales y personas afectadas por la calificación”, Revista Catalana de Dret Public, no 14, 2011, pp. 97-105.

${ }^{27}$ No es pacífica la respuesta jurídica ante ciertas estrategias empleadas para obtener ventajas fiscales indebidas o perjudicar intereses de terceros (como puede ser los socios minoritarios, los acreedores y los trabajadores). A este respecto, E. SCHOLLMEYER, “Die „künstliche Gestaltung“ - der Herr Tur Tur unter den Rechtsfiguren”, Neue Zeitschrift für Gesellschaftsrecht, 25, 2018, pp. 977-978; European Company Law Experts, The Commission's 2018 Proposal on Cross-Border Mobility - An Assessment, September 2018, disponible en https://europeancompanylawexperts.wordpress.com/publications/the-commissions-2018-proposal-on-cross-border-mobility-an-assessment-september-2019/.

${ }^{28}$ D. ZetzSCHE, "Know Your Shareholder. Der intermediärsgestützte Aktionärsbegriff und das Hauptversammlungsverfahren: zur Umsetzung des Kapitels Ia der reformierten AktionärsrechteRL“, Zeitschrift für Gesellschaftsrecht, no 1, 2019, pp. 1-38.

${ }^{29}$ A. B. Perdices Huetos "Los asesores de voto", en AA.VV., Estudios de derecho mercantil: liber amicorum profesor Dr. Francisco Vicent Chuliá, Valencia, Tirant lo Blanch, 2013, pp. 569-580; A. GAllego Córcoles, Asesores de voto ("proxy advisors") y el ejercicio del derecho de voto en las sociedades cotizadas, Cizur Menor (Navarra), Aranzadi, 2014; A. EMPARANZA Sobejano, "Asesores de voto: Transparencia y alcance de las recomendaciones de voto", en A. Roncero SÁnchez (coord.), Sociedades cotizadas y transparencia en los mercados, vol. 1, 2019, pp. 1423-1452. Sobre este aspecto concreto en el marco de la Directiva, J. Boquera Matarredonda, "Las entidades asesoras de voto para la implicación de los socios en las sociedades cotizadas según la Directiva 2017/828”, Revista de Derecho Mercantil, n 306, 2017, pp. 459-485. 
robotizado cobra fuerza, como próximo hito en el uso de herramientas digitales por los prestadores de este servicio (bien el asesor, bien un tercero), de modo que lo pueda emitir automáticamente tanto una plataforma como una aplicación del gestor de activos, sobre la base de las indicaciones formuladas por el proxy advisor ${ }^{30}$.

\section{La gestación subrogada transfronteriza}

9. Fue en la década de los setenta del pasado siglo cuando comenzaron a aparecer fórmulas alternativas para colmar los deseos de formar una familia cuando no era posible mediante la reproducción tradicional, conociéndose por las siglas TRHA (técnicas de reproducción humana asistida). Desde su inicio, las TRHA han planteado problemas jurídicos muy variados, particularmente, como es lógico, en el sector del Derecho civil de familia y, por extensión, en el del Derecho de familia internacional, dada su contribución a la configuración de los distintos modelos de familia -heteroparental, homoparentales y monoparental- que conviven en la actualidad y, en particular, a la expansión de la noción de filiación. Una de esas técnicas -al menos, denominada como tal por la OMS- ha hecho correr auténticos ríos de tinta, especialmente, en la última década ${ }^{31}$. Se trata de la denominada "gestación subrogada" o también "maternidad por sustitución". Existe así un amplísimo debate doctrinal, a nivel nacional e internacional, donde se han planteado y analizado cuestiones esenciales sobre tal figura, desde los más diversos puntos de vista (médico, psicológico, ético, económico, jurídico...), confrontando la diferentes posiciones presentes en torno al fenómeno; sin olvidar aportaciones como la del propio Tribunal Europeo de Derechos Humanos (TEDH), particularmente relevantes en materia de inscripción de este tipo de filiación en supuestos transfronterizos, como es sabido. Por su parte, también el legislador español se ha

\footnotetext{
${ }^{30}$ T. M. DoyLE, "The realities of robo-voting", American Council for Capital Formation, noviembre de 2018 (https://accfcorpgov.org/wp-content/uploads/ACCF-RoboVoting-Report_11_8_FINAL.pdf).

${ }^{31}$ Tan solo en España, y sin ánimo de exhaustividad, se pueden citar al menos los siguientes trabajos sobre este asunto: S. Álvarez GonzÁlez, "Efectos en España de la gestación por sustitución llevada a cabo en el extranjero", Anuario Español de Derecho Internacional Privado, vol. X, 2010, pp. 339-377; I. Brena Sesma, "Maternidad subrogada”, en C. M. Romeo CASABoNA, (Dir.), Enciclopedia de Bioderecho y Bioética, tomo II, Granada, Comares, 2011; M. J. CABEZUdo BAJo, "Avances hacia una regulación de la gestación por sustitución en España en base al modelo regulado en el Estado de California”, Revista de Derecho y Genoma Humano, no 46, 2017; A. L. Calvo Caravaca; J. Carrascosa González, "Gestación por sustitución y Derecho Internacional Privado. Más allá del Tribunal Supremo y del Tribunal Europeo de Derechos Humanos”, Cuadernos de Derecho Transnacional, $\mathrm{n}^{\circ}$ 7, octubre 2015; M. CORERA Izu, "Maternidad subrogada: la solución única, de momento, el registro civil", Revista Jurídica La Ley, no 8813, 28 julio 2016; E. Corral GARCía, "El derecho a la reproducción humana. ¿Debe permitirse la maternidad subrogada?, Revista de Derecho y Genoma Humano, no 38, 2013; J. R. De Verda y Beamonte, "Inscripción de hijos nacidos mediante gestación por sustitución (a propósito de la sentencia del Juzgado de Primera Instancia número 15 de Valencia, de 15 de septiembre de 2010)", Revista Jurídica La Ley, no 7501, 3 noviembre 2010; A. Durán Ayago, "Gestación por sustitución en España: a hard case needs law. De por qué la jurisprudencia no puede resolver este problema", Cuadernos de Derecho transnacional, vol. 11, $\mathrm{n}^{\circ} .2,2019$, pp. 575-582; id. "El acceso al Registro civil de certificaciones registrales extranjeras a la luz de la Ley 20/2011: relevancia para los caos de filiación habida a través de gestación por sustitución”, Anuario Español de Derecho internacional privado, vol. XII, 2012, pp. 265-308; E. FARnós Amorós, Consentimiento a la reproducción asistida. Crisis de pareja y disposición de embriones, Atelier, Barcelona, 2011; J. FloREs RodRíGUEz, "Vientres de alquiler: más cerca de su reconocimiento legal en España", Revista Jurídica La Ley, no 8363, 28 julio 2014; M. GuzMÁn Zapater, "Gestación por sustitución y nacimiento en el extranjero: hacia un modelo de regulación”, Anuario Español de Derecho Internacional Privado, vol. X, 2010, pp. 731-743; I. Heredia Cervantes, "La Dirección General de los Registros y del Notariado ante la gestación por sustitución”, Anuario de Derecho Civil, vol. LXVI, nº 2, 2013; F. J. JiMÉNEZ MuÑOz, La reproducción asistida y su régimen jurídico, Ed., Reus, Madrid, 2012; E. LAmm, "La importancia de la voluntad procreacional en la nueva categoría de filiación derivada de las técnicas de reproducción asistida", Revista de Biotética y Derecho, n 24, 2012; C. LASARTE, "La reproducción asistida y la prohibición legal de la maternidad subrogada admitida de hecho por vía reglamentaria", Revista Jurídica La Ley, $\mathrm{n}^{\circ}$ 7777, 17 enero 2012; J. M. MartíneZ-Pereda Rodríguez y Moreno Sánchez-Moraleda, "La determinación legal de la filiación mediante gestación de sustitución reconocida en el derecho internacional privado español", Revista Aranzadi, $\mathrm{n}^{\circ}$ 9, $2014 ; \mathrm{M}$. A. SÁez-Saturtún Prieto, "La maternidad subrogada: estado actual de la cuestión a raíz de la STS de 6 de febrero de 2014", Revista Jurídica La Ley, no 8293, 15 de abril 2014; P. A. TALAVERA Fernández, "Maternidad subrogada: ficción jurídica contra verdad biológica", Revista de Derecho y Genoma Humano, 2017, nº 2; A. J. Vela SánChez, "Problemas prácticos del convenio de gestación por sustitución o de maternidad subrogada en nuestro ordenamiento jurídico", Revista de Derecho de Familia, $\mathrm{n}^{\circ}$. 53, 2011, pp. 67 y ss.; id., La maternidad subrogada: estudio ante un reto normativo, Granada, Comares, 2012; id., Técnicas de gestación por encargo: tratamiento judicial y soluciones prácticas para su eficacia en España, Madrid, Reus, 2015.
} 
enfrentado con los problemas de la infertilidad a la vez que se consolidaban los tres modelos de familia que coexisten hoy en España ${ }^{32}$. Como consecuencia de dicho marco, se atribuye la filiación por naturaleza a los padres de intención aunque, en ciertos casos, no aporten su material genético. En particular, la gestación por sustitución fue regulada tanto por la LTRHA 14/2006 como por su predecesora, la Ley 35/1988, pero para dejar sin efecto el contrato entre la gestante y los padres de intención ${ }^{33}$; siendo esa falta de autorización precisamente uno de los factores que ha contribuido a desencadenar el incremento exponencial de los casos de subrogación transfronteriza, junto con la evolución de las técnicas médicas y la permisividad a estos efectos por parte de numerosos países extranjeros.

10. Lejos de estar cerrado, el debate sobre la regulación de la gestación subrogada -a nivel interno y, por tanto, también transfronterizo- continúa vigente ${ }^{34}$. Y la Conferencia Internacional de La Haya no ha sido ajena al mismo, estando su Oficina Permanente pendiente del estudio de los problemas de Derecho internacional privado relativos a la paternidad legal, así como en relación con los acuerdos internacionales de subrogación. De este modo, en 2015, el Consejo de Asuntos Generales y Política (CGAP) decidió que se debería convocar un Grupo de Expertos para explorar la viabilidad de avanzar en el trabajo en esta área ${ }^{35}$, a partir especialmente de su estudio previo llevado a cabo en $2014^{36}$. La parte del estudio que interesa destacar aquí es el apartado B, donde se expone un panorama del Derecho internacional privado comparado y las reglas de cooperación que conciernen a este asunto ${ }^{37}$. Así, la parte central de dicho capítulo se subdivide en cinco grandes apartados: a) registro del nacimiento y establecimiento de la paternidad, b) posible reconocimiento de la paternidad ya establecida en el extranjero, c) normas de Derecho internacional privado relativas a la impugnación de la paternidad ${ }^{38}$, d) efectos

\footnotetext{
${ }^{32}$ La Ley 14/2006, de 26 de mayo, regula las TRHA; en concreto, la inseminación artificial, la fecundación in vitro e inyección intracitoplásmica de espermatozoides con gametos propios o de donante y con transferencia de embriones, así como la transferencia intratubárica de gametos (Anexo A de la LTRHA). Por su parte, a la Ley 15/2005, de 8 de julio, por la que se modifican el Código Civil y la Ley de Enjuiciamiento Civil en materia de separación y divorcio, se suman la Ley 13/2005, de 1 de julio que prevé el matrimonio homosexual (junto con las distintas Leyes autonómicas reguladoras de las parejas de hecho) y la LO 3/2007, de 22 de marzo, reguladora de la igualdad entre el hombre y la mujer. El problema de las implicaciones transfronterizas de los matrimonios del mismo sexo también ha sido ampliamente tratada por la doctrina española; en este sentido, vid., por todos, en general, A. L. Calvo Caravaca y J. Carrascosa GonzÁlez, "Los matrimonios entre personas del mismo sexo en la UE", Revista Crítica de Derecho Inmobiliario, no 700, 2007, pp. 443-475. Más reciente, sobre los aspectos patrimoniales, A. Rodríguez Benot, "Los efectos patrimoniales de los matrimonios y de las uniones registradas en la UE", Cuadernos de Derecho Transnacional, vol. 11, no 1, 2019, pp. 8-50; id., "Cuestionario práctico sobre los Reglamentos de la UE 2016/1103 (matrimonios) y 2016/1104 (uniones registradas)", La Notaria, nº 1, 2019, pp. 81-89.

${ }^{33} \mathrm{El}$ art. $10.1^{\circ}$ LTRHA $14 / 2006$ ha previsto la nulidad de dicho contrato y en sus párrafos $2^{\circ}$ y $3^{\circ}$ se establecen las consecuencias legales de dicha nulidad al señalar, respectivamente, que la "filiación de los hijos nacidos por gestación de sustitución será determinada por el parto" y que "queda a salvo la posible acción de reclamación de la paternidad respecto del padre biológico, conforme a las reglas generales" (en virtud de los arts. 764 y ss. de la LEC, que regulan las acciones a llevar a cabo para la determinación legal de la filiación).

${ }^{34}$ En España, ha habido a este respecto propuestas de regulación auspiciadas por grupos sociales (como la Asociación para la Gestación Subrogada de España y la Sociedad Española de Fertilidad) así como por el partido político Ciudadanos (Proposición de Ley $n^{\circ}$ 20170627).

${ }^{35}$ Hasta ahora, las reuniones del Grupo de Expertos se han celebrado en febrero de 2016, enero-febrero de 2017, febrero de 2018, septiembre de 2018, enero-febrero de 2019 y octubre-noviembre de 2019 (informes disponibles en https://www.hcch.net/ es/projects/legislative-projects/parentage-surrogacy). En marzo de 2020, el CGAP renovó el mandato del Grupo de Expertos por dos años y respaldó la continuación del trabajo de acuerdo con el último informe, señalando que el trabajo debería centrarse en desarrollar un instrumento general de derecho internacional privado sobre el reconocimiento de decisiones judiciales extranjeras sobre filiación legal; así como un protocolo separado sobre el reconocimiento de decisiones judiciales extranjeras de paternidad legal dictadas como resultado de acuerdos internacionales de subrogación. Circula, no obstante, una petición en redes de la denominada CIAMS (Coalición Internacional para la Abolición de la Maternidad Subrogada) para solicitar la paralización del proyecto, alegando que supondría la legalización de facto a nivel internacional de una práctica de explotación reproductiva.

${ }^{36}$ Disponible en https://assets.hcch.net/docs/bb90cfd2-a66a-4fe4-a05b-55f33b009cfc.pdf.

${ }^{37}$ El estudio incluye otros dos grandes bloques: el primero (A) se refiere al establecimiento e impugnación de la filiación en Derecho interno; el último (C) desarrolla un análisis más exhaustivo de los convenios en materia de gestación subrogada internacional.

${ }^{38}$ Sobre estas cuestiones con carácter general en Derecho internacional privado español, vid., por todos, D. ADAm MuÑoz, "La nueva regulación de la filiación natural en el derecho internacional privado español", Cuadernos de Derecho Transnacional, vol. 8/2, 2016, pp. 34-54.
} 
jurídicos del reconocimiento y e) desarrollos legales en Derecho internacional privado. En relación con el primer núcleo de cuestiones (a), se distinguen cuatro grupos de Estados, para la asunción de competencia sobre el nacimiento en el extranjero del menor cuyo registro se pretende: aquéllos en que la única circunstancia en que las autoridades competentes asumirán jurisdicción para registrar el nacimiento de un niño es que se haya informado del nacimiento en el territorio de su Estado (por lo que no es posible el registro cuando se produjo en el extranjero); aquéllos que permiten el registro cuando uno de los padres es nacional de tal Estado, aunque el nacimiento fuera en el extranjero; los que, en general, no permiten el registro de nacimiento en el extranjero, salvo en situaciones limitadas (p.e., si el registro no ha sido posible en el Estado de nacimiento); y un Estado que permitía hasta 2014 (Suecia) registrar el nacimiento en el extranjero si la madre figuraba en su registro. En cuanto al segundo núcleo de cuestiones (b), el posible reconocimiento de la paternidad establecida en el extranjero, el informe distingue según el documento que se aporte: o bien un certificado de nacimiento extranjero (donde se concluye que la mayoría de los Estados lo reconocen siempre que sea válido según la ley aplicable de acuerdo con su propio sistema conflictual), o bien un reconocimiento voluntario (para el que una mayoría de Estados aplican el mismo criterio que en el caso anterior), o bien una resolución judicial extranjera (donde la mayoría de los Estados aplican su sistema de reconocimiento de resoluciones judiciales). Sobre el tercer grupo de problemas (c), se concluye que en la mayoría de los Estados la impugnación de la filiación tiene lugar ante la jurisdicción ordinaria. En cuanto a los efectos jurídicos del reconocimiento (d), en una mayoría de Estados se trata de una cuestión que queda regida por su ley del foro (aunque en algunos existe una norma específica de Derecho internacional privado). Y en relación con la última cuestión (e) se destaca que el desarrollo normativo principal en los Estados sobre este conjunto de materias se refiere, precisamente, a la gestación subrogada, de modo específico.

11. Por lo que se refiere al caso concreto de España, es de público conocimiento que existen actualmente dos vías para poder reconocer la filiación de menores nacidos a raíz del empleo de esta técnica reproductiva -llevada a cabo Estados extranjeros donde está autorizada- en favor de los padres de intención, cuando uno o ambos sean españoles, para poder otorgar dicha nacionalidad al hijo o hija. La primera se utiliza cuando la filiación en favor de los padres sea reconocida mediante sentencia en el Estado de origen. A tal efecto, la DGRN (hoy DGSJFP) dictó el 5 de octubre de 2010 una Instrucción sobre el régimen registral de la filiación de los nacidos mediante gestación por sustitución ${ }^{39}$, exigiendo la presentación ante el Encargado del Registro civil de una resolución judicial dictada por el Tribunal competente del Estado de origen -no bastando la certificación registral extranjera, ni el certificado médico de nacimiento donde no conste identidad de la gestante- con "la finalidad de controlar el cumplimiento de los requisitos de perfección y contenido del contrato respecto del marco legal del país donde se ha formalizado, así como la protección de los intereses del menor y de la madre gestante. En especial, permite constatar la plena capacidad jurídica y de obrar de la mujer gestante, la eficacia legal del consentimiento prestado por no haber incurrido en error sobre las consecuencias y alcance del mismo, ni haber sido sometida a engaño, violencia o coacción o la eventual previsión y/o posterior respeto a la facultad de revocación del consentimiento o cualesquiera otros requisitos previstos en la normativa legal del país de origen. Igualmente, permite verificar que no existe simulación en el contrato de gestación por sustitución que encubra el tráfico internacional de menores". La Instrucción exige asimismo que la resolución judicial extranjera se haya dictado en el marco de un procedimiento equivalente a uno español de jurisdicción voluntaria. La segunda vía posible apuntada se refiere a casos en que la filiación no se haya reconocido en una sentencia, sino mediante una decisión dictada por una autoridad administrativa o notarial competente según el Derecho del Estado de origen, o a través de una certificación de asientos extendidos en registros extranjeros; aplicándose en tales casos lo dispuesto en la Instrucción de la DGRN 18 febrero 2019, sobre actualización del régimen registral de la filiación de los nacidos mediante gestación por sustitución ${ }^{40}$.

\footnotetext{
${ }^{39}$ La STS 8 febrero 2014 dejó sin efecto esta Instrucción, aunque la DGRN reconfirmó su eficacia mediante una Circular 11 julio 2014. Posteriormente, se aprobó la Instrucción 18 febrero 2019, sobre actualización del régimen registral de la filiación de los nacidos mediante gestación por sustitución, que también ha respetado la vigencia de la Instrucción de 2010.

${ }^{40}$ La jurisprudencia española ha venido diferenciando dos cuestiones: por un lado, la filiación de los menores nacidos
} 


\section{La sociedad de la hiperinformación}

\section{La transferencia internacional de datos desde la UE}

12. La transferencia de datos personales es a la sociedad de la información lo que la gestación subrogada al Derecho de familia: un auténtico trending topic ${ }^{41}$; con el agravante de que, además, el núcleo de problemas que se aborda en este caso es más amplio y complejo técnicamente que en el anterior, al menos, en opinión de quien suscribe. Por ello, considerando el ya de por sí denso contenido del presente trabajo a estas alturas, se ha optado aquí por limitar el análisis a la transferencia internacional de datos prevista por el Reglamento (UE) 2016/67942 (o RGPD) obviando otros asuntos que también son de interés, como puede ser -especialmente, en términos de Derecho internacional privado- el relativo a la responsabilidad (no solo extracontractual, sino también contractual), que deberá quedar aparcado de momento, a la espera de ocasión más propicia. Aun así, la exposición de la parte apuntada deberá también ser resumida, dada la prolijidad con la que ha sido objeto de regulación en el citado reglamento, como se verá seguidamente. Así, cabe comenzar indicando que el RGPD dedica un capítulo entero (el V) a la transferencias de datos personales a terceros países u organizaciones internacionales, del artículo 44 al 50 (ambos inclusive); todos ellos son bastante extensos y detallados, salvo quizás el primero, que establece el principio general a tener en cuenta y que se sirve de base a todos los restantes desarrollos: "solo se realizarán transferencias de datos personales que sean objeto de tratamiento o vayan a serlo tras su transferencia a un tercer país u organización internacional si, a reserva de las demás disposiciones del presente Reglamento, el responsable y el encargado del tratamiento cumplen las condiciones establecidas en el presente capítulo, incluidas las relativas a las transferencias ulteriores de datos personales desde el tercer país u organización internacional a otro tercer país u otra organización internacional. Todas las disposiciones del presente capítulo se aplicarán a fin de asegurar que el nivel de protección de las personas físicas garantizado por el presente Reglamento no se vea menoscabado". El principio fun-

mediante un proceso transfronterizo. La doctrina contenida en la STS 6 febrero 2014, que dejó sin efecto la Instrucción de la DGRN 5 octubre 2010, fue confirmada por el ATS 2 febrero 2015, dictado a causa de un incidente de nulidad de actuaciones planteado tras dos sentencias del TEDH, 26 junio 2014, Mennesson vs. Francia y Labasseé vs. Francia. Para el TS, era imposible reconocer eficacia transnacional a la filiación establecida en una certificación registral extranjera en favor de los padres de intención por impedirlo el art 10 LTRHA, que integra el orden público internacional español (pese al certero voto particular en contra); se limitó así a dar cumplimiento a la jurisprudencia del TEDH considerando que el padre de intención, siendo el padre genético, podía reclamar la paternidad según lo previsto en los arts. 746 y ss LEC, siendo su madre legal la gestante y pudiendo la madre de intención adoptar al hijo de su cónyuge o pareja (art. 1762 2. $2^{\circ}$ C.c.). Al proyectar esta solución sobre todos los casos de gestación por sustitución, independientemente de que en el Estado de origen se hubiese dictado una sentencia de filiación, se dejó así sin efecto la citada Instrucción de la DGRN de 2010, como se indicó. Por otro lado, la segunda cuestión abordada por nuestra jurisprudencia se refiere a la prestación por maternidad, que el TS ha atribuido a los padres de intención cuya filiación ya esté reconocida en España tras haber realizado un proceso de gestación por sustitución en un Estado donde está autorizado legalmente (SSTS 25 octubre y 16 noviembre 2016).

${ }^{41} \mathrm{Si}$, como ya se vio supra, la cantidad de bibliografía relativa a gestación subrogada transfronteriza es mareante, la que se refiere a la transferencia internacional de datos no se queda corta. Para no fatigar más de lo debido al/a lector/a, se recomienda aquí la recopilada por A. ORTEGA GimÉnez, La (des)protección del titular del derecho a la protección de datos derivada de una transferencia internacional ilicita en Derecho internacional privado español, Tesis Doctoral, Universidad de Alicante, 2014, disponible en https://pdfs.semanticscholar.org/75e4/3da3d67f0e8c092782cfd8f161b46543b485.pdf; así como la más actualizada incluida en la edición correspondiente a 2019 del Manual de legislación europea en materia de protección de datos, disponible en https://fra.europa.eu/sites/default/files/fra_uploads/fra-coe-edps-2018-handbook-data-protection_es.pdf.

42 Reglamento (UE) 2016/679, del Parlamento Europeo y del Consejo, de 27 de abril de 2016, relativo a la protección de las personas físicas en lo que respecta al tratamiento de datos personales y a la libre circulación de estos datos y por el que se deroga la Directiva 95/46/CE (Reglamento general de protección de datos). DOUE L/119, 4 de mayo de 2016. Este Reglamento ha sido la base de la LO 3/2018, de 5 de diciembre, de Protección de Datos Personales y garantía de los derechos digitales (BOE de 6 de diciembre). A este respecto, cabe mencionar que, recientemente, por lo que se refiere a la transmisión transfronteriza, el Real Decreto-ley 26/2020, de 7 de julio, de medidas de reactivación económica para hacer frente al impacto del COVID-19 en los ámbitos de transportes y vivienda (BOE de 8 de julio) incluyó en el párrafo cuarto de su Disposición Adicional primera lo siguiente: "el intercambio de datos con otros países se regirá por el Reglamento general de protección de datos (UE) 2016/679 del Parlamento Europeo y del Consejo, de 27 de abril de 2016, teniendo en cuenta la Decisión n. ${ }^{\circ}$ 1082/2013/UE del Parlamento Europeo y del Consejo, de 22 de octubre de 2013, sobre las amenazas transfronterizas graves para la salud y por la que se deroga la Decisión n² 2119/98/CE". 
damental a considerar es, por tanto, el del país de origen de la transferencia, pero con un decisivo matiz, exigiendo estándares comparables a los europeos para autorizar la misma. Para articularlo, se establece un sistema en cascada, que va desde la posibilidad de una decisión (política -o técnica, si se prefiere) sobre la adecuación de los estándares manejados en el extranjeros; pasando por el establecimiento de una serie de garantías, en su defecto; hasta la sujeción a varias condiciones, en último lugar; permitiendo, asimismo, que las empresas se puedan dotar voluntariamente de un conjunto de normas corporativas vinculantes al efecto (conocidas también como BCR, por sus siglas en inglés). Se examinará a continuación someramente el contenido básico de cada uno de estos mecanismos.

13. El artículo 45 RGPD regula las transferencias basadas en una decisión de adecuación. Como principio, se establece en su párrafo primero que "podrá realizarse una transferencia de datos personales a un tercer país u organización internacional cuando la Comisión haya decidido que el tercer país, un territorio o uno o varios sectores específicos de ese tercer país, o la organización internacional de que se trate garantizan un nivel de protección adecuado". La transferencia no requerirá así de ninguna autorización específica, decidiendo la Comisión mediante un acto de ejecución (pár. $3^{\circ}$ ) tras evaluar la adecuación sobre la base de los parámetros indicados en el párrafo segundo ${ }^{43}$, estableciendo un mecanismo de revisión periódica, al menos cada cuatro años, que tenga en cuenta todos los acontecimientos relevantes en el tercer país o en la organización internacional ${ }^{44}$. Las decisiones a tal efecto serán públicas en la web de la Comisión (según indica el párrafo 8) donde, a día de hoy figuran los siguientes países: Suiza, Canadá, Argentina, Andorra, Israel, Uruguay, Nueva Zelanda y Japón ${ }^{45}$. En el caso de Estados Unidos, hasta fecha reciente, regía la Decisión de ejecución (UE) 2016/1250, de 12 de julio de 2016, sobre la adecuación de la protección conferida por el denominado "Privacy Shield" o "Escudo de Privacidad"46. Pero la STJUE 16 julio 2020, Schrems, 311/18, por reclamación de una persona física cuyos datos fueron transferidos de la Unión Europea a Estados Unidos, ha invalidado tal Decisión. Las consecuencias

43 “a) el Estado de Derecho, el respeto de los derechos humanos y las libertades fundamentales, la legislación pertinente, tanto general como sectorial, incluida la relativa a la seguridad pública, la defensa, la seguridad nacional y la legislación penal, y el acceso de las autoridades públicas a los datos personales, así como la aplicación de dicha legislación, las normas de protección de datos, las normas profesionales y las medidas de seguridad, incluidas las normas sobre transferencias ulteriores de datos personales a otro tercer país u organización internacional observadas en ese país u organización internacional, la jurisprudencia, así como el reconocimiento a los interesados cuyos datos personales estén siendo transferidos de derechos efectivos y exigibles y de recursos administrativos y acciones judiciales que sean efectivos; b) la existencia y el funcionamiento efectivo de una o varias autoridades de control independientes en el tercer país o a las cuales esté sujeta una organización internacional, con la responsabilidad de garantizar y hacer cumplir las normas en materia de protección de datos, incluidos poderes de ejecución adecuados, de asistir y asesorar a los interesados en el ejercicio de sus derechos, y de cooperar con las autoridades de control de la Unión y de los Estados miembros, y c) los compromisos internacionales asumidos por el tercer país u organización internacional de que se trate, $\mathrm{u}$ otras obligaciones derivadas de acuerdos o instrumentos jurídicamente vinculantes, así como de su participación en sistemas multilaterales o regionales, en particular en relación con la protección de los datos personales".

${ }^{44}$ Considerando la cautela establecida en el párrafo quinto, según el cual "cuando la información disponible, en particular tras la revisión a que se refiere el apartado 3 del presente artículo, muestre que un tercer país, un territorio o un sector específico de ese tercer país, o una organización internacional ya no garantiza un nivel de protección adecuado a tenor del apartado 2 del presente artículo, la Comisión, mediante actos de ejecución, derogará, modificará o suspenderá, en la medida necesaria y sin efecto retroactivo, la decisión"; aunque, según lo dispuesto en el párrafo sexto "la Comisión entablará consultas con el tercer país u organización internacional con vistas a poner remedio a la situación que dé lugar a la decisión adoptada de conformidad con el apartado 5".

${ }^{45}$ Respectivamente, decisiones de la Comisión 2000/518/CE, 26 julio 2000; 2002/2/CE, 20 diciembre 2001; 2003/490/ CE, 3 junio 2003; 2010/625/UE, 19 octubre 2010; 2011/61/UE, 31 enero 2011; 2012/484/UE, 21 agosto 2012; 2013/65/UE, 19 diciembre 2012; y decisión 2019/149/UE, 23 enero 2019.

${ }^{46}$ El Escudo de la privacidad UE-EE. UU. se basa en un sistema de autocertificación por el que las entidades estadounidenses se comprometen a cumplir una serie de principios de protección de la vida privada (los principios marco del Escudo de la privacidad UE-EE. UU., incluidos los principios complementarios establecidos por el Departamento de Comercio de Estados Unidos). Se aplica tanto a los responsables como a los encargados del tratamiento (agentes), con la particularidad de que los encargados deben estar obligados contractualmente a actuar únicamente siguiendo instrucciones del responsable del tratamiento de la UE y asistir a este último a responder a las personas físicas que ejerzan sus derechos con arreglo a los principios. Una aproximación general al Privacy Shield en J. F. López AgulLar, "La protección de datos personales en la más reciente jurisprudencia del TJUE: los derechos de la CDFUE como parámetro de validez del Derecho Europeo y su impacto en la relación trasatlántica UE-EE.UU.”, UNED. Teoría y Realidad Constitucional, n 39, 2017, pp. 557-581. 
del tsunami que desencadenará esta sentencia en la política trasatlántica de tráfico internacional de datos están todavía por determinar, hasta el punto de que la Agencia Europea de Protección de Datos (EDPB) se vio obligada a elaborar un documento para el cumplimiento de sentencia por los órganos de la Unión ${ }^{47}$. Así, tras explicar el fallo, se aclara que el TJUE "ha considerado que los requisitos de la legislación nacional de los Estados Unidos, y en particular algunos programas de vigilancia que permiten el acceso de las autoridades públicas de los Estados Unidos a los datos personales transferidos desde la UE a los Estados Unidos con fines de seguridad nacional, dan lugar a limitaciones a la protección de los datos personales que no están circunscritas de manera que satisfagan requisitos que son esencialmente equivalentes a los exigidos por la legislación de la UE, y que esta legislación no otorga derechos recurribles ante los tribunales contra las autoridades de los Estados Unidos". En suma, como consecuencia, las transferencias de datos basadas en este marco son, al momento de redactar estas líneas, ilegales ${ }^{48}$.

14. Por su parte, el artículo 46 regula las transferencias internacionales de datos mediante una serie de garantías que se consideran adecuadas. Este mecanismo opera en defecto de Decisión de ejecución, con arreglo al apartado anterior. Las garantías pueden ser aportadas -sin que se requiera autorización expresa de una autoridad de control- mediante una amplia variedad de instrumentos ${ }^{49}$, que se ven incluso ampliados cuando media permiso de la autoridad de control competente ${ }^{50}$. Entre las fórmulas previstas de garantía, se encuentra las cláusulas tipo de protección de datos adoptadas por la Comisión, como las que se recogen en la Decisión 2010/87/UE de la Comisión, de 5 de febrero de 2010 (relativa a las cláusulas contractuales tipo para la transferencia de datos personales a los encargados del tratamiento establecidos en terceros países, de conformidad con la Directiva 95/46/CE). En la misma, se indica, entre otros aspectos, que las autoridades competentes de los EE.MM. podrán prohibir las transferencias de datos en tres casos: a) si se determina que la legislación a la que está sujeto el importador de datos o un subencargado del tratamiento le impone desviaciones de la legislación de protección de datos aplicable que vayan más allá de las restricciones necesarias en una sociedad democrática, como establece el artículo 13 de la Directiva 95/46/CE, cuando tales exigencias puedan tener un importante efecto negativo sobre las garantías proporcionadas por las cláusulas contractuales tipo, o b) si una autoridad competente decide que el importador de datos o un subencargado del tratamiento no ha respetado las cláusulas contractuales tipo del anexo, o c) si existe la probabilidad sustancial de

${ }^{47}$ EDBP, Strategy for Union institutions, offices, bodies and agencies to comply with the 'Schrems II' Ruling, Bruselas, 29 octubre 2020 (disponible en https://edps.europa.eu/sites/edp/files/publication/2020-10-29_edps_strategy_schremsii_en_0. pdf). El Supervisor Europeo ha publicado asimismo una nota informativa sobre la transferencia de datos después del Brexit, que está disponible en https://edps.europa.eu/sites/edp/files/publication/19-07-16_for_translation_note_on_personal_data_transfers_post-brexit_en.pdf

${ }^{48}$ El Tribunal subraya que determinados programas de vigilancia que permiten el acceso de las autoridades públicas de los EE.UU a los datos personales transferidos de la UE a los EE.UU con fines de seguridad nacional no prevén limitaciones a la facultad conferida a las autoridades de los EE.UU., ni la existencia de garantías para personas que no sean estadounidenses. El umbral establecido por el TJUE se aplica también a todas las salvaguardias adecuadas- con arreglo al artículo 46 del RGPD- utilizadas para transferir datos del EEE a cualquier tercer país. La legislación estadounidense mencionada por el TJUE (la sección 702 de la FISA y la EO 12333) se aplica a cualquier transferencia a EE.UU. por medios electrónicos que entren en el ámbito de aplicación de la misma, independientemente del instrumento de transferencia utilizado. Por otra parte, dado que el Escudo de Privacidad también fue diseñado para dar garantías a los datos transferidos con otros instrumentos como las BCR (normas corporativas vinculantes), la evaluación del Tribunal se aplica también en el contexto de las mismas.

${ }^{49}$ Son los que establece el párrafo segundo: a) un instrumento jurídicamente vinculante y exigible entre las autoridades $\mathrm{u}$ organismos públicos; b) normas corporativas vinculantes de conformidad con el artículo 47; c) cláusulas tipo de protección de datos adoptadas por la Comisión de conformidad con el procedimiento de examen a que se refiere el artículo 93, apartado 2; d) cláusulas tipo de protección de datos adoptadas por una autoridad de control y aprobadas por la Comisión con arreglo al procedimiento de examen a que se refiere en el artículo 93, apartado 2; e) un código de conducta aprobado con arreglo al artículo 40 , junto con compromisos vinculantes y exigibles del responsable o el encargado del tratamiento en el tercer país de aplicar garantías adecuadas, incluidas la relativas a los derechos de los interesados, o f) un mecanismo de certificación aprobado con arreglo al artículo 42, junto con compromisos vinculantes y exigibles del responsable o el encargado del tratamiento en el tercer país de aplicar garantías adecuadas, incluidas la relativas a los derechos de los interesados.

${ }^{50}$ Mediante el recurso a: a) cláusulas contractuales entre el responsable o el encargado y el responsable, encargado o destinatario de los datos personales en el tercer país u organización internacional, o b) disposiciones que se incorporen en acuerdos administrativos entre las autoridades $u$ organismos públicos que incluyan derechos efectivos y exigibles para los interesados. 
que las cláusulas contractuales tipo contenidas en el anexo no se estén respetando, o no se respeten en el futuro, y la continuación de la transferencia provoque un riesgo inminente de daños graves para los interesados. Fuera del cumplimiento de las garantías previstas, el artículo 49 establece una serie de excepciones para situaciones específicas (al margen de las BCR, que se examinan a continuación) en las que se permite la transferencia ${ }^{51}$. En caso contrario, "solo se podrá llevar a cabo si no es repetitiva, afecta solo a un número limitado de interesados, es necesaria a los fines de intereses legítimos imperiosos perseguidos por el responsable del tratamiento sobre los que no prevalezcan los intereses o derechos y libertades del interesado, y el responsable del tratamiento evaluó todas las circunstancias concurrentes en la transferencia de datos y, basándose en esta evaluación, ofreció garantías apropiadas con respecto a la protección de datos personales" ${ }^{\prime 52}$.

15. Finalmente, el artículo 47 RGPD se refiere a las denominadas "normas corporativas vinculantes" (o BCR por sus siglas en ingles); esto es, "las políticas de protección de datos personales asumidas por un responsable o encargado del tratamiento establecido en el territorio de un Estado miembro para transferencias o un conjunto de transferencias de datos personales a un responsable o encargado en uno o más países terceros, dentro de un grupo empresarial o una unión de empresas dedicadas a una actividad económica conjunta" ${ }^{\text {"3 }}$. Dichas normas serán aprobadas por la autoridad de control competente -según el mecanismo de coherencia previsto en el artículo 63- siempre que: a) sean jurídicamente vinculantes y se apliquen y sean cumplidas por todos los miembros correspondientes del grupo empresarial o de la unión de empresas dedicadas a una actividad económica conjunta, incluidos sus empleados; b) confieran expresamente a los interesados derechos exigibles en relación con el tratamiento de sus datos personales, y c) cumplan los requisitos establecidos en el apartado $2^{54}$. A tal

${ }^{51}$ La transferencia, en este contexto, se realizará únicamente si se cumple alguna de las condiciones siguientes: a) el interesado haya dado explícitamente su consentimiento a la transferencia propuesta, tras haber sido informado de los posibles riesgos para él de dichas transferencias debido a la ausencia de una decisión de adecuación y de garantías adecuadas; b) la transferencia sea necesaria para la ejecución de un contrato entre el interesado y el responsable del tratamiento o para la ejecución de medidas precontractuales adoptadas a solicitud del interesado; c) la transferencia sea necesaria para la celebración o ejecución de un contrato, en interés del interesado, entre el responsable del tratamiento y otra persona física o jurídica; d) la transferencia sea necesaria por razones importantes de interés público; e) la transferencia sea necesaria para la formulación, el ejercicio o la defensa de reclamaciones; f) la transferencia sea necesaria para proteger los intereses vitales del interesado o de otras personas, cuando el interesado esté física o jurídicamente incapacitado para dar su consentimiento; g) la transferencia se realice desde un registro público que, con arreglo al Derecho de la Unión o de los Estados miembros, tenga por objeto facilitar información al público y esté abierto a la consulta del público en general o de cualquier persona que pueda acreditar un interés legítimo, pero sólo en la medida en que se cumplan, en cada caso particular, las condiciones que establece el Derecho de la Unión o de los Estados miembros para la consulta.

${ }^{52}$ Por otra parte, el artículo 48 RGPD, como cierre del sistema, impone que "cualquier sentencia de un órgano jurisdiccional o decisión de una autoridad administrativa de un tercer país que exijan que un responsable o encargado del tratamiento transfiera o comunique datos personales únicamente será reconocida o ejecutable en cualquier modo si se basa en un acuerdo internacional, como un tratado de asistencia jurídica mutua, vigente entre el país tercero requirente y la Unión o un Estado miembro, sin perjuicio de otros motivos para la transferencia al amparo del presente capítulo" (subrayado propio).

${ }^{53}$ Disponible en la dirección www.aepd.es/es/derechos-y-deberes/cumple-tus-deberes/medidas-de-cumplimiento/transferencias-internacionales.

${ }^{54}$ Deberán especificar los siguientes aspectos: a) la estructura y los datos de contacto del grupo empresarial o de la unión de empresas dedicadas a una actividad económica conjunta y de cada uno de sus miembros; b) las transferencias o conjuntos de transferencias de datos, incluidas las categorías de datos personales, el tipo de tratamientos y sus fines, el tipo de interesados afectados y el nombre del tercer o los terceros países en cuestión; c) su carácter jurídicamente vinculante, tanto a nivel interno como externo; d) la aplicación de los principios generales en materia de protección de datos, en particular la limitación de la finalidad, la minimización de los datos, los periodos de conservación limitados, la calidad de los datos, la protección de los datos desde el diseño y por defecto, la base del tratamiento, el tratamiento de categorías especiales de datos personales, las medidas encaminadas a garantizar la seguridad de los datos y los requisitos con respecto a las transferencias ulteriores a organismos no vinculados por las normas corporativas vinculantes; e) los derechos de los interesados en relación con el tratamiento y los medios para ejercerlos, en particular el derecho a no ser objeto de decisiones basadas exclusivamente en un tratamiento automatizado, incluida la elaboración de perfiles de conformidad con lo dispuesto en el artículo 22, el derecho a presentar una reclamación ante la autoridad de control competente y ante los tribunales competentes de los Estados miembros de conformidad con el artículo 79, y el derecho a obtener una reparación, y, cuando proceda, una indemnización por violación de las normas corporativas vinculantes; f) la aceptación por parte del responsable o del encargado del tratamiento establecidos en el territorio de un Estado miembro de la responsabilidad por cualquier violación de las normas corporativas vinculantes por parte de cualquier 
efecto, para facilitar el uso de las BCR para responsables (BCR-C) y para encargados de tratamiento (BCR-P) por un grupo empresarial o un grupo de empresas dedicadas a una actividad económica conjunta para transferencias internacionales de organizaciones establecidas en la UE a organizaciones dentro del mismo grupo establecido fuera de la UE, el Grupo de Trabajo del Artículo 29 (WP29) estableció una mesa con los elementos y principios que se encuentran en las BCR, con el fin de reflejar los requisitos necesarios, haciendo referencia expresamente RGPD. Como resultado, se han elaborado sendos documentos ${ }^{55}$ que recogen las obligaciones en relación con los datos personales de terceros que son procesados por un miembro del grupo como responsable o encargado. Asimismo, el grupo que solicita la aprobación de sus BCR puede tener entidades en más de un Estado Miembro, por lo que el procedimiento puede involucrar a varias autoridades de supervisión interesadas, por ejemplo, en aquellos países desde donde se realizarán las transferencias. Sin embargo, el RGPD no establece reglas específicas para la fase de cooperación que debería tener lugar entre tales autoridades interesadas antes de la remisión a la Agencia Europea. Tampoco establece reglas específicas para identificar la autoridad competente que deberá actuar como Autoridad Principal para los BCR (o "BCR Lead" ${ }^{56}$ ). De ahí que un tercer documento ${ }^{57}$ establezca los procedimientos para una cooperación fluida y eficaz en este contexto, en línea con el RGPD, aprovechando la experiencia previa de las Autoridades de Protección de Datos al tratar la aprobación de BCR.

\section{El Bloqueo geográfico de interfaces en línea}

16. El de 28 de febrero de 2018 se aprobó el Reglamento 2018/302/UE, sobre medidas destinadas a impedir el bloqueo geográfico injustificado y otras formas de discriminación por razón de la nacionalidad, del lugar de residencia o del lugar de establecimiento de los clientes en el mercado interior [y por el que se modifican los Reglamentos (CE) 2006/2004 y (UE) 2017/2394 y la Directiva 2009/22/ CE]. Ya desde el primero de sus dos primeros considerandos queda clara cual la finalidad de mismo, así como el problema a combatir. Así, se parte de que, para lograr el pleno potencial del mercado interior, no basta con suprimir las barreras entre los EE.MM. creadas por los propios Estados. Esa supresión

miembro de que se trate no establecido en la Unión; el responsable o el encargado solo será exonerado, total o parcialmente, de dicha responsabilidad si demuestra que el acto que originó los daños y perjuicios no es imputable a dicho miembro; g) la forma en que se facilita a los interesados la información sobre las normas corporativas vinculantes, en particular en lo que respecta a las disposiciones contempladas en las letras d), e) y f) del presente apartado, además de los artículos 13 y 14; h) las funciones de todo delegado de protección de datos designado de conformidad con el artículo 37, o de cualquier otra persona o entidad encargada de la supervisión del cumplimiento de las normas corporativas vinculantes dentro del grupo empresarial o de la unión de empresas dedicadas a una actividad económica conjunta, así como de la supervisión de la formación y de la tramitación de las reclamaciones; i) los procedimientos de reclamación; j) los mecanismos establecidos dentro del grupo empresarial o de la unión de empresas dedicadas a una actividad económica conjunta para garantizar la verificación del cumplimiento de las normas corporativas vinculantes. Dichos mecanismos incluirán auditorías de protección de datos y métodos para garantizar acciones correctivas para proteger los derechos del interesado. Los resultados de dicha verificación deberían comunicarse a la persona o entidad a que se refiere la letra h) y al consejo de administración de la empresa que controla un grupo empresarial, o de la unión de empresas dedicadas a una actividad económica conjunta, y ponerse a disposición de la autoridad de control competente que lo solicite; k) los mecanismos establecidos para comunicar y registrar las modificaciones introducidas en las normas y para notificar esas modificaciones a la autoridad de control; 1) el mecanismo de cooperación con la autoridad de control para garantizar el cumplimiento por parte de cualquier miembro del grupo empresarial o de la unión de empresas dedicadas a una actividad económica conjunta, en particular poniendo a disposición de la autoridad de control los resultados de las verificaciones de las medidas contempladas en la letra j); m) los mecanismos para informar a la autoridad de control competente de cualquier requisito jurídico de aplicación en un país tercero a un miembro del grupo empresarial o de la unión de empresas dedicadas a una actividad económica conjunta, que probablemente tengan un efecto adverso sobre las garantías establecidas en las normas corporativas vinculantes, y n) la formación en protección de datos pertinente para el personal que tenga acceso permanente o habitual a datos personales.

${ }_{55}$ Disponibles, respectivamente, en este vínculo https://www.aepd.es/sites/default/files/2019-09/wp256_en.pdf y en este otro https://www.aepd.es/sites/default/files/2019-09/wp257_en.pdf.

${ }^{56}$ Ser BCR Lead incluye actuar como un único punto de contacto con la organización o grupo solicitante durante el proceso de aprobación y la gestión del procedimiento de solicitud en su fase de cooperación.

${ }^{57}$ Disponible en https://www.aepd.es/sites/default/files/2019-09/wp263_en_0.pdf. 
puede verse también socavada por obstáculos creados por los propios particulares y que son incompatibles con las libertades del mercado interior. Así sucede, por ejemplo, cuando los comerciantes que ejercen su actividad en un E.M. bloquean o limitan el acceso a sus interfaces en línea, tales como sitios web y aplicaciones, a clientes de otros EE.MM. que desean realizar transacciones transfronterizas (o «bloqueo geográfico»). También sucede cuando determinados comerciantes aplican a esos clientes de otros EE.MM. condiciones generales de acceso diferentes a sus productos y servicios, tanto en línea como fuera de línea. En algunos casos, tal práctica podría justificarse objetivamente, pero no en la mayoría. Existen así diversas razones por las que empresas (sobre todo, pymes), aplican condiciones generales de acceso diferentes. En muchas ocasiones, los entornos jurídicos divergentes, la incertidumbre jurídica que ello implica, los riesgos asociados a la legislación aplicable en materia de protección de los consumidores, la legislación en materia de medio ambiente o etiquetado, las cuestiones tributarias y fiscales, los gastos de entrega o los requisitos lingüísticos, contribuyen a que los comerciantes sean reacios a entablar relaciones comerciales con los clientes de otros EE.MM. En otras ocasiones, los comerciantes segmentan artificialmente el mercado interior según las fronteras interiores y dificultan la libre circulación de mercancías y servicios, limitando los derechos de los clientes e impidiéndoles disfrutar de posibilidades de elección más amplias y unas condiciones óptimas. Estas prácticas discriminatorias contribuyen al nivel relativamente bajo de transacciones transfronterizas en la UE, incluso en el sector del comercio electrónico, impidiendo alcanzar el pleno potencial de crecimiento del mercado interior. Por todo ello, el Reglamento pretende determinar las situaciones en que no puede haber ninguna justificación para un trato diferenciado, aportando así claridad y seguridad jurídica a cuantos participan en las transacciones transfronterizas, garantizando la aplicación y el cumplimiento efectivo de normas contra la discriminación en todo el mercado interior. En suma, se entiende que eliminar el bloqueo geográfico injustificado y otras formas de discriminación por razón de la nacionalidad, del lugar de residencia o del lugar de establecimiento de los clientes podría impulsar el crecimiento y aumentar las opciones de los consumidores en todo el mercado interior ${ }^{58}$.

17. En el contexto que se acaba de exponer, no se puede olvidar que, según el Reglamento Roma I, la elección de la ley aplicable a los contratos entre un consumidor y un profesional que ejerza sus actividades comerciales o profesionales en el país en que el consumidor tenga su residencia habitual o que, por cualquier medio, dirija tales actividades a ese país o a varios países, incluido ese país, no puede tener por consecuencia privar al consumidor de la protección que le proporcionen disposiciones que no puedan, en virtud de la ley del país en que el consumidor tenga su residencia habitual, excluirse mediante acuerdo. Y también que, de conformidad con el Reglamento Bruselas I bis, en lo que respecta a un contrato entre un consumidor y una persona que ejerza actividades comerciales o profesionales en el Estado miembro del domicilio del consumidor o que, por cualquier medio, dirija tales actividades a ese Estado miembro o a varios Estados miembros, incluido ese Estado miembro, el consumidor podrá interponer una acción contra la otra parte ante los órganos jurisdiccionales del Estado miembro en que el consumidor tenga su domicilio y se podrá iniciar una acción contra el consumidor solo ante esos órganos jurisdiccionales. Por todo ello, el Reglamento 2018/302/UE debe entenderse sin perjuicio del Derecho de la Unión relativo a la cooperación judicial en materia civil y, en particular, de las disposiciones sobre la ley aplicable a las obligaciones contractuales y sobre la competencia judicial establecidas en los Reglamentos Roma I y Bruselas I bis, respectivamente. En particular, como se señala en el considerando 13, del mero hecho de que un comerciante cumpla el Reglamento sobre bloqueo geográfico no debe derivarse que dirige sus actividades al E.M. del consumidor en el sentido del artículo 6, apartado 1, letra b), del Reglamento Roma I y/o del artículo 17, apartado 1, letra c), del Reglamento Bruselas I bis. Por consiguiente, el mero hecho de que el comerciante no bloquee o no limite el acceso a una interfaz

\footnotetext{
${ }^{58}$ Se quiere hacer frente tanto a la discriminación directa como a la indirecta; por tanto, también a las diferencias injustificadas de trato por razón de otros criterios de distinción que conducen al mismo resultado con los basados directamente en la nacionalidad o el lugar de residencia del cliente (independientemente de si el cliente en cuestión está presente, de forma permanente o temporal, en otro E.M., o en su lugar de establecimiento). Esos criterios pueden aplicarse, en particular, basándose en información que indique la ubicación física de los clientes, como la dirección IP utilizada al acceder a una interfaz en línea, la dirección facilitada para la entrega de mercancías, la elección de lengua o el E.M. de emisión del instrumento de pago del cliente (cdo. 6).
} 
en línea por los consumidores de otro E.M., no aplique condiciones generales de acceso diferentes en los casos previstos en el Reglamento 2018/302/UE, o no aplique condiciones distintas a las operaciones de pago entre los diversos medios de pago aceptados, no debe, por sí mismo, dar a entender que el comerciante dirige sus actividades al E.M. del consumidor a efectos de determinar la ley aplicable y la competencia judicial. Tampoco debe entenderse, únicamente por dichos motivos, que el comerciante dirige sus actividades al E.M. en que el consumidor tiene su domicilio o residencia habitual cuando el comerciante facilita información y asistencia al consumidor tras la celebración del contrato, conforme a las obligaciones que le incumben en virtud del Reglamento sobre bloqueo geográfico ${ }^{59}$.

\section{La gobernanza contractual en las plataformas digitales}

18. La economía de plataforma se caracteriza por la existencia de una estructura (o "plataforma") que permite transacciones mediante la conexión de dos partes contractuales, ya sea para la compra de un bien, ya sea para la prestación de un servicio. En consecuencia, la plataforma sirve como un punto de encuentro que se basa en la acción externa para generar un producto o servicio complementario a la plataforma misma, cuya característica principal es la presencia de efectos de red, de modo que, cuanto mayor sea el número de usuarios, más atractivo se vuelve ${ }^{60}$. A través de sus términos y condiciones (en general, apresuradamente aceptados por los usuarios), estas plataformas en línea se convierten en reguladores de segmentos significativos de la población y de la economía mundial. Los problemas legales que acarrea este tipo economía digital exigen soluciones alternativas a las pensadas para un entorno analógico, que no resultan siempre útiles ante el nuevo panorama. De hecho, un enfoque regulatorio basado únicamente en leyes podría llegar incluso a parecer incompatible con los nuevos paradigmas contractuales que ofrecen las empresas de plataformas, construidos en gran medida en torno parámetros de reputación y la confianza, surgiendo así reglas privadas creadas espontáneamente como una respuesta a las necesidades transformadas de protección del consumidor ${ }^{61}$. De este modo, mientras tales plataformas continúan su desarrollo y ofrecen sus propias soluciones normativas, los regímenes regulatorios existentes luchan por responder a los desafíos que éstas plantean, ante tal aparición (espontánea) de normas generadas por las propias plataformas y, en menor medida, por la comunidad de usuarios. En vista de ello, la autorregulación se ha convertido en una característica común de las empresas de plataformas, que operan principalmente en Internet, liderando así un proceso abierto de innovación regulatoria, en

${ }^{59}$ Tal es la explicación del artículo 1.6 . "El presente Reglamento se entenderá sin perjuicio del Derecho de la Unión relativo a la cooperación judicial en materia civil. Del cumplimiento del presente Reglamento no se derivará que un comerciante dirige sus actividades al Estado miembro de residencia habitual o domicilio del consumidor en el sentido del artículo 6, apartado 1, letra b), del Reglamento (CE) no 593/2008 y del artículo 17, apartado 1, letra c), del Reglamento (UE) n ${ }^{\circ} 1215 / 2012$. En particular, cuando un comerciante, que actúa de conformidad con los artículos 3, 4 y 5 del presente Reglamento, no bloquea ni limita el acceso de los consumidores a su interfaz en línea, no redirige a los consumidores a una versión de su interfaz en línea basada en la nacionalidad o lugar de residencia delos mismos diferente de la interfaz en línea a la que hubiesen tratado de acceder inicialmente, no aplica condiciones generales de acceso diferentes al vender productos o prestar servicios en los supuestos previstos en el presente Reglamento, o acepta instrumentos de pago emitidos en otro Estado miembro de manera no discriminatoria, no se considerará, únicamente por esos motivos, que dicho comerciante dirige sus actividades al Estado miembro en que el consumidor tiene su domicilio o residencia habitual. Tampoco se considerará, únicamente por dichos motivos, que el comerciante facilita información y asistencia al consumidor tras la celebración del contrato conforme a las obligaciones que le incumben en virtud del presente Reglamento".

${ }^{60}$ Según S. P. Choudary, M.W Van Alstyne, y G. G. Parker, Platform Revolution: How Networked Markets Are Transforming the Economy-And How to Make Them Work for You, New York/London, Norton, 2016, las grandes plataformas digitales se asemejarían a los Estados-nación.

${ }^{61}$ Los desarrollos que siguen son deudores, esencialmente, de las ideas de M. CANTERO GAMITO en este ámbito, en particular, las vertidas en su artículo "Regulation.com. Self-regulation and Contract Governance in the Platform Economy: A research agenda”, European Journal of Legal Studies, vol. 9, $\mathrm{n}^{\circ}$ 2, 2017, pp. 53-67. Otras aportaciones de la autora en el mismo campo son 'The Role of the EU in the Making of Global Standards for ICT and Telecommunications', Yearbook of European Law, vol. 37, 2018, pp. 395 ss; y The role of the EU in Transnational Legal Ordering: Standards, Contracts, and Codes, Edward Elgar Publishing, Chelteham, 2020 (con H. W. MickLitz, ambos coeditores). Sobre los nuevos retos a los que se enfrenta el Derecho del consumo transfronterizo, desde el punto de vista contractual, vid. el reciente trabajo de A. L. CALvo CARAVACA, "Los contratos de consumo en la jurisprudencia del TJUE. Últimas tendencias”, Cuadernos de Derecho Transnacional, vol. 12, nº 1, 2020, pp. 86-96. 
atención a las transformaciones económicas, tecnológicas y sociales en curso, ofreciendo una solución alternativa a la cambiante sociedad hipermoderna y colmando lagunas normativas. Tales innovaciones constituyen la respuesta del mercado a las demandas de regulación del entorno digital, que las formas convencionales de legislación y aplicación (judicial y extrajudicial) no pueden replicar fácilmente. El uso de servicios prestados en el contexto de la economía colaborativa desemboca así en una autoexclusión de la regulación ${ }^{62}$, lo que conduce a un proceso de desregulación y, en última instancia, a la autorregulación, donde posiblemente pueden corregirse errores de diseño normativo mediante la creación por parte de la industria de estándares de calidad que, a su vez, funcionan como un dispositivo para una gobernanza transnacional. Tal proceso conlleva implicaciones para la teoría reguladora más convencional, que hacen necesario repensar la naturaleza y el papel de estas normas y procesos emergentes "post-regulatorios" ${ }^{63}$.

19. Los marcos de gobernanza de las plataformas se basan en gran medida en mecanismos de reputación y confianza. Además, tales mecanismos y los códigos de conducta que sustentan el comercio electrónico se complementan a menudo con la existencia de un procedimiento de resolución de disputas en línea (ODR) dedicado a dirimir las controversias que surjan en relación con transacciones dentro de la propia plataforma. Esas herramientas reputacionales (feedback y ratings) pueden llegar así a convertirse en auténtica fuente de normas pues, al retroalimentar y calificar los servicios utilizados o los productos adquiridos, las empresas y los usuarios de las plataformas están generando "espontáneamente" nuevas reglas; algo particularmente acusado cuando las calificaciones de los usuarios se utilizan como punto de referencia, al resolver una disputa privada bajo un procedimiento de solución de controversias integrado en la propia plataforma. De este modo, el sistema reputacional se erige como una forma novedosa de abordar los errores del mercado y los problemas de información asimétrica, fuera de cualquier procedimiento oficial de elaboración de leyes; lo que acaba incluso teniendo eventual impacto no solo en términos de diseño contractual, sino también regulatorio, dada su efectividad probada como alternativa a las soluciones tradicionales para la protección del consumidor. Si bien el enfoque dominante hasta ahora viene demandando una reforma de la legislación sobre contratos y consumidores en la UE, para poder acomodar nuevas relaciones triangulares en las que se basan las transacciones de plataforma (y salvaguardar los intereses de los consumidores, extendiendo la responsabilidad a los consumidores intermediarios de la plataforma); otras miradas cautelosas ya han propuesto como solución el uso de categorías no legales y la autorregulación, aunque solo en combinación con la regulación ${ }^{64}$. Pero cabría incluso un tercer enfoque, más audaz, partiendo de la autorregulación espontánea de las plataformas digitales como un marco de gobernanza que surge de abajo hacia arriba: desde las calificaciones de los usuarios hasta la elaboración, a partir de las mismas, de concretos estándares de calidad ${ }^{65}$.

\footnotetext{
${ }^{62}$ La exclusión voluntaria de la regulación -entendida como adopción de un enfoque de autorregulación basado en reglas y prácticas creadas por la comunidad- ya ha demostrado ser una estrategia satisfactoria en ciertos sectores (L. BERNSTEIN, "Opting Out of the Legal System: Extralegal Contractual Relations in the Diamond Industry”, The Journal of Legal Studies, vol. 21, 1992, pp. 115 y ss., p. 57; id., "Private Commercial Law in the Cotton Industry: Creating Cooperation Through Rules, Norms, and Institutions", University of Chicago Law \& Economics, Olin Working Paper, $\mathrm{n}^{\circ}$ 133, 2001); aunque algún autor sea reacio al uso de mecanismos de reputación como un reemplazo total de la regulación (C. Busch, "Crowdsourcing Consumer Confidence: How to Regulate Online Rating and Review Systems in the Collaborative Economy”, en A. De FrancEsChI (Coord.), European Contract Law and the Digital Single Market, Cambridge, Intersentia, 2016, pp. 223-243).

63 M. CAntero Gamito, "Regulation.com...", loc. cit., p. 60.

${ }^{64}$ La Economía de Plataforma exige así una nueva generación de regulación (Regulación 2.0) basada en la transparencia de la información y la rendición de cuentas basada en datos (N. Grossman, "Regulation the Internet Way: a data-first model for establishing trust, safety and security", Regulatory Reform for the 21st Century City (Project), 2015). En este contexto, mientras algunos afirman que la economía de plataformas requiere un marco regulatorio específico (O. LoBEL, "The Law of the Platform", Minnesota Law Review, 2016, p. 212 y ss.), otros defienden las ventajas de la autorregulación como herramienta para atraer nuevos negocios innovadores y rentables (C. Koopman, M. Mitchell y A. Thierer, "The Sharing Economy and Consumer Protection Regulation: The Case for Policy Change", The Journal of Business, Entrepreneurship \& the Law, vol. 8, 2015; M. Cohen y A. Sundararajan, "Self Regulation and innovation in the Peer-to-Peer Sharing Economy", University of Chicago Law Review, vol. 82, 2015, p. 116).

${ }^{65}$ M. CAntero Gamito, "Regulation.com...", loc. cit., passim.
} 
20. El actual entorno tecnológico ha cambiado ciertamente las reglas del juego, dando lugar a nuevos modos de poder, gobernanza y propiedad ${ }^{66}$. Esto ha implicado una transformación también en la gobernanza transnacional, donde la estandarización se coloca en el núcleo central del sistema emergente, de modo que las técnicas autorreguladoras de estándares, códigos de conducta o mejores prácticas se observan como impulsores privilegiados de un proceso de descentralización reguladora ${ }^{67}$. Como resultado, las realidades institucionales emergentes ya no están aplicando en muchos casos la ley, sino más investigando el cumplimiento de estándares autoestablecidos ${ }^{68}$. Volvemos así a Adam Smith (1759) y nos encontramos ante un auténtico sistema de "retroalimentación de reputación", apoyado ahora en las calificaciones y los indicios de calidad, que se genera en gran medida de forma espontánea, a partir de los comentarios de los usuarios, originando estándares de calidad. Un régimen fundamentado en la confianza, donde la ejecución del contrato se asienta sobre un compromiso creíble garantizado ${ }^{69}$. Se trata, en suma, de un proceso de revisión por pares que asegura el cumplimiento de unos requisitos mínimos de calidad ${ }^{70}$. Bajo el modelo descrito, los estándares actuarían como "jueces privados" ", contribuyendo a que el mecanismo reputacional se vea como más eficaz que la ley, al menos "como medio para promover el comercio (...) y transmitir la información suficiente a las personas adecuadas en las circunstancias adecuadas"72. Las soluciones de autorregulación espontánea basadas en un modelo de gobernanza de "comunitarismo en red"73 son una respuesta posible a los desafios de legitimidad, efectividad y conexión regulatoria ${ }^{74}$. La plataforma digital actúa así como un guardián del mercado, siempre que el comerciante desee seguir operando a través de la plataforma y mejorar -o, al menos, mantener- su historial de reputación, pudiendo verse entonces como un ejemplo de regulación cooperativa, basada en la autoorganización y el autocompromiso; mientras que el diseño de sus contratos ofrece el ejemplo paradigmático de una de las manifestaciones de la gobernanza privada (la "gobernanza mediante contrato" $)^{75}$. Ahora bien, los mecanismos de reputación pueden ser vulnerables al sesgo y al abuso. La creación de estándares internacionales que establezcan garantías procesales se erige como una solución a los problemas de diseño que plantean los marcos de reputación; pero resta por evidenciar que las plataformas ejerzan efectivamente control sobre el flujo de información recibido, para poder evaluar si están canalizando efectivamente la opinión colectiva y estableciendo nuevos estándares de calidad basados en las expectativas de sus usuarios/as.

${ }^{66}$ M. NAIM, The End of Power: from boardrooms to battlefields and churches to states, why being in charge isn't what it used to be, New York, Basic Books, 2014.

${ }^{67}$ J. BLACK, "Decentring Regulation: Understanding the Role of Regulation and Self-Regulation in a 'Post-Regulatory' World”, Current Legal Problems, vol. 54, nº 2001, pp. 103 y ss. Así, en el campo de la reputación online, la Organización Internacional de Normalización (ISO) propone la estandarización de métodos, herramientas, procesos, medidas y mejores prácticas relacionadas con la reputación online de organizaciones o personas que prestan servicios o productos, derivados de contenido generado por el usuario (ISO / TC 290 - Reputación online). La creación de esta norma global se basa en el modelo desarrollado por la Asociación Francesa de Normalización, AFNOR, en 2013 (AFNOR, French Standard NF Z 74-501 - Avis en ligne de consommateurs - Principes et exigencies portant sur les processus de collecte, moderation et restitution des avis en ligne de consommateurs, 19 julio de 2013). La estandarización internacional se convierte de esta forma en una solución alternativa de respaldo regulatorio ideada para problemas de diseño institucional.

${ }^{68}$ H. W. Micklitz, "The Transformation of Enforcement in European Private Law: Preliminary Considerations", European Review of Private Law, vol. 23, n 4, 2015, pp. 491-524. Sobre estas cuestiones, con carácter general, en la doctrina española destaca el trabajo de C. Otero GARCÍA-CASTRILlón, "Autoregulación y establecimiento de estándares en los contratos internacionales", Anuario Español de Derecho internacional privado, vol. VIII, 2008, pp. 329-356.

${ }^{69}$ D. C. NorTh, "Institutions and Credible Commitment", Journal of Institutional and Theoretical Economics (JITE)/ Zeitschrift für die gesamte Staatswissenschaft, 1993, pp. 11-23.

${ }^{70}$ J. Heimans y H. Timms, “Understanding 'New Power'”, Harvard Business Review, vol. 92, no 12, 2016, pp. 15 y ss.

${ }^{71}$ O. Williamson, "Economic Institutions: Spontaneous and Intentional Governance", Journal of Law, Economics \& Organization, vol. 7, 1991, pp. 159 y ss.

${ }^{72}$ P. R. Milgrom y D. C. North, "The Role of Institutions in the Revival of Trade: The Law Merchant, Private Judges, and the Champagne Fairs", Economics \& Politics, vol. 2, nº1, 1990, pp. 1 y ss.

${ }^{73}$ A. Murray, Information Technology Law: the Law and Society, Oxford, Oxford University Press, 2016 ( $3^{\mathrm{a}}$ ed.).

${ }^{74}$ R. Brownsword y M. Goodwin, Law and the Technologies of the Twenty-first Century: Text and Materials, Cambridge, Cambridge University Press, 2012.

${ }^{75}$ S. Grundmann, F. Möslein y K. Riesenhuber (eds.), Contract Governance: Dimensions in Law and Interdisciplinary Research, Oxford, Oxford University Press, 2015. 


\section{La justicia civil transfronteriza low-cost de la UE}

\section{La plataforma de la UE para resolución en línea de litigios en materia de consumo.}

21. Mucho se ha escrito sobre la relación de proporcionalidad directa entre un diseño eficiente de los mecanismos alternativos de resolución de conflictos y el incremento de la confianza en el merca$\mathrm{do}^{76}$. Y, ciertamente, en el marco de la economía de plataformas que domina en la sociedad de la hiperinformación, cuyos rasgos principales se acaban de describir en el epígrafe anterior, el recurso por parte de los consumidores a tales mecanismos está alterando tanto el papel de los reguladores como el suyo propio. Esta narrativa se amplifica además con la introducción de tecnologías digitales en la gestión de disputas (ODR). Ahora bien, el objetivo principal de las plataformas digitales no es ofrecer un modelo de ODR exitoso, sino más bien proporcionar un lugar para la resolución de conflictos como complemento orgánico de las transacciones que se realizan a través de las mismas. Estos "espacios integrados" para la resolución de disputas se erigen así como un auténtico mecanismo sancionador, separado no solo de la ejecución judicial, sino también de manifestaciones más genéricas de ODR. Por otro lado, al incluir las plataformas digitales la participación en la resolución de disputas como parte de sus términos y condiciones, ofrecen incentivos efectivos para que los comerciantes participen en dicha resolución. Tal vez, todo ello explique el hecho de que, así como eBay maneja millones de casos por año ${ }^{77}$, en cambio, ni la mitad de los comerciantes de la UE declaraban hace pocos años conocer la existencia de estos ODR ${ }^{78}$. Probablemente, otra razón que contribuye a aclarar tal disparidad de uso se encuentre en el propio diseño de los mecanismos integrados de resolución de disputas, así como en la falta de incentivos eficaces para que los comerciantes se involucren en procedimientos de ODR, como sucede precisamente con la Plataforma EU-ODR ${ }^{79}$, que ha resultado en el archivo automático de más de la mitad del total de quejas presentadas, dada la falta de respuesta de aquéllos. En todo caso, con el fin de superar los desafíos de legitimidad y de procedimiento que plantean estos mecanismos de resolución de litigios en línea, al menos en Europa, tales procedimientos se han dotado con una combinación de garantías procesales ex ante (certificación) y ex post (seguimiento), como muestra la normativa de la UE, a saber, la Directiva 2013/11/UE, de 21 de mayo de 2013, relativa a la resolución alternativa de litigios en materia de consumo, así como el Reglamento (UE) 524/2013, de 21 de mayo de 2013, sobre resolución de litigios en línea en materia de consumo que, dada su relación directa con el objeto del presente epígrafe, será analizado brevemente a continuación ${ }^{80}$.

\footnotetext{
${ }^{76}$ Entre otros muchos, P. CoRTés, The Law of Consumer Redress in an Evolving Digital Market, Cambridge, Cambridge University Press, 2017; E. Katsh, O. Rabinovich-Einy y R. Susskind, Digital Justice: Technology and the Internet of Disputes, Oxford, Oxford University Press, 2017; J. Hornle, Cross-Border Internet Dispute Resolution, Cambridge, Cambridge University Press, 2009; G. Kaufmann-Kohler y T. Schultz, Online Dispute Resolution: Challenges for Contemporary Justice, La Haya, Kluwer Law International, 2004.

${ }^{77}$ UK Civil Justice Council, Online Dispute Resolution for Law Value Civil Claims (Online Dispute Resolution Advisory Group), 2015; disponible en https://www.judiciary.gov.uk/wp-content/uploads/2015/02/Online-Dispute-Resolution-Final-Web- Version1.pdf.

${ }^{78}$ Comisión Europea, Settling consumer disputes online, Factsheet, enero de 2016.

79 EU-Online Dispute Resolution Platform, disponible en su versión en español en la dirección https://ec.europa.eu/consumers/odr/main/index.cfm?event=main.home2.show\&lng=ES).

${ }^{80}$ Resulta inabordable detenerse aquí a analizar el régimen de los ADR instaurado por la Directiva 2013/11/UE, traspuesta al ordenamiento español mediante la Ley 7/2017, de 2 de noviembre. Y sería además osado, considerando que ya existe, en el marco general, la obra dirigida por G. Palao Moreno (ed.), Los nuevos instrumentos europeos en materia de conciliación, mediación y arbitraje de consumo. Su incidencia en España, Irlanda y el Reino Unido, Tirant lo Blanch, Valencia, 2016; del mismo autor, "Autonomía de la voluntad y mediación en conflictos transfronterizos en el Real Decreto-Ley 5/2012", Diario La Ley, núm. 7847, 2012 (versión online); y teniendo en cuenta además que, en el sector concreto de la mediación, destaca la obra de referencia en España e Iberoamérica dirigida por C. Esplugues Mota, Mediación civil y comercial. Regulación internacional e iberoamerciana, Tirant lo Blanch, Valencia, 2019 (del mismo autor, se puede consultar asimismo "El régimen jurídico de la mediación civil y mercantil en conflictos transfronterizos en España tras la ley 5/2012, de 6 de julio", Boletín Mexicano de Derecho Comparado, vol. 46, n 136, 2013, pp. 165-199, entre otros varios trabajos sobre los medios alternativos de resolución de conflictos). Sobre la mediación en la concreta materia de familia, P. DiAGo DiAGO, "Aproximación a la mediación familiar desde el derecho internacional al privado", en A. L. Calvo Caravaca y E. Castellanos Ruiz (Coords.), La Unión Europea ante el derecho de la globalización, Madrid, Colex, 2008, pp. 265-298; de esta misma autora, con carácter general, puede consultarse
} 
22. El Reglamento 524/2013 pretende "contribuir, a través de la consecución de un elevado nivel de protección del consumidor, al correcto funcionamiento del mercado interior, en particular en su dimensión digital, proporcionando una plataforma europea de resolución de litigios en línea que facilite la resolución extrajudicial de litigios entre consumidores y comerciantes en línea de forma independiente, imparcial, transparente, eficaz y equitativa" (artículo 1). Las entidades acreditadas disponen así de una plataforma configurada como un proveedor de información a nivel europeo sobre resolución de litigios en línea de consumo y como un nexo de contacto entre las partes implicadas en un conflicto, sin que se introduzcan mecanismos de negociación asistida o automática ${ }^{81}$, limitada al comercio en línea ${ }^{82}$ y concebida como una ventanilla única ${ }^{83}$, siendo la Comisión responsable de su funcionamiento. El Reglamento, a diferencia de la Directiva 2013/11, puede aplicarse a la resolución de los conflictos iniciados por un comerciante frente a un consumidor, cuando la ley del E.M. de residencia habitual del consumidor permita que tales conflictos se resuelvan a través de una entidad de resolución alternativa de conflictos, conforme a lo previsto en su art. $2^{84}$. Además, el art. 7 establece la obligación para cada E.M. de establecer un punto de contacto de resolución de conflictos online, tarea que se puede conferir a la Red de Centros Europeos del Consumidor. El procedimiento se ha diseñado para sustanciarse en cuatro pasos: a) se inicia con la presentación de la reclamación, a través de un formulario electrónico que la parte reclamante deberá rellenar íntegramente y se transmitirá de un modo fácilmente comprensible y sin demora a la parte reclamada, en una de las lenguas oficiales de las instituciones de la Unión por la que haya optado dicha parte; b) presentada la reclamación, se exige elegir un organismo de resolución de litigios de común acuerdo, que recibirá la reclamación y tramitará el arbitraje telemático (de no haber acuerdo, la reclamación cesa su tramitación) disponiendo de un plazo máximo de 30 días al respecto ${ }^{85}$; c) en tercer lugar, el organismo de resolución de litigios elegido por las partes tramita la reclamación: comunicada la entidad de resolución alternativa, la plataforma transmitirá la reclamación automáticamente y sin demora a dicha entidad, la cual informará a las partes de su aceptación, junto con las normas de procedimiento y, en su caso, las costas del mismo; o la negativa a tramitarlo; d) el procedimiento concluye con la comunicación a las partes del proceso del resultado y cierre del expediente ${ }^{86}$. Pero la

\footnotetext{
"Modelos normativos para una regulación de los marc (mecanismos alternativos de resolución de conflictos)", en A. L. CALVo Caravaca y J. Carrascosa González (Coords.), Estudios sobre contratación internacional, Madrid, Colex, 2006, pp. 151-178. Finalmente, cabe mencionar también en este sector los trabajos de P. CoRTÉs, "Un nuevo derecho europeo para la resolución alternativa y en línea de litigios de consumo", en F. EsteBAN DE LA Rosa, (Coord.), La protección del consumidor en dos espacios de integración: Europa y América. Una perspectiva del Derecho internacional, europeo y comparado, Valencia, Tirant lo Blanch, 2015, pp. 560-561; id., The Law of consumer Redress in an Evolving Digital Market: upgrading from Alternative to Online Dispute Resolution, Cambridge, Cambridge University Press, 2017.

${ }^{81}$ D. CARrizo Aguado, “Asistencia extrajudicial al consumidor transfroterizo europeo", Cuadernos de Derecho Transnacional, vol. 10-1, 2018, pp. 45-69, p. 64; J. SuQuet CAPDEVILla, "El marco europeo de resolución de litigios en línea (RLL) de consumo: ¿tecnologías al servicio de la resolución de litigios?, en G. PaLao Moreno (ed.), Los nuevos instrumentos europeos... cit., p. 270.

${ }^{82}$ El Reglamento será de aplicación a la resolución extrajudicial de litigios relativos a obligaciones contractuales derivadas de contratos de compraventa o de prestación de servicios celebrados en línea entre un consumidor residente en la Unión y un comerciante establecido en la Unión mediante la intervención de una entidad de resolución alternativa incluida en la lista con arreglo al artículo $20.2^{\circ}$, de la Directiva 2013/11/UE, en la que intervenga una plataforma de resolución de litigios en línea. Para F. Valbuena GonzÁlez, "La protección del consumidor europeo: alternativas a la vía judicial”, Revista de estudios europeos, $\mathrm{n}^{\mathrm{o}} .66,2015$, p. 68 , esta limitación, que excluye el comercio tradicional, no estaría justificada.

${ }^{83}$ Lo que parece un acierto a M. RichARD GonZÁLEz, "Los procedimientos electrónicos de resolución alternativa de conflictos: (on-line dispute resolution)”, Diario La Ley, nº 8360, 2014, versión en línea.

${ }^{84}$ Sobre esta circunstancia se deberá informar a la Comisión, especificándose en las listas previstas del art. 20.2 de la Directiva cuáles son las entidades de resolución alternativa competentes para conocer de tales litigios.

${ }^{85}$ Si la parte reclamada es un comerciante, se le requiere a fin de que declare en un plazo de diez días naturales si se compromete o está obligado a recurrir a una entidad de resolución alternativa concreta para resolver los litigios con consumidores y, salvo en caso de que esté obligado a recurrir a una entidad de resolución alternativa concreta, si está dispuesto a recurrir a cualesquiera de las entidades de resolución alternativa a que se refiere art. 9.3.b). Si la parte reclamada es un consumidor y el comerciante está obligado a recurrir a una entidad de resolución alternativa concreta, se le requiere a aceptar en el plazo de diez días naturales dicha entidad o, en caso de que el comerciante no esté obligado a recurrir a una entidad de resolución alternativa concreta, a que seleccione una o más de las entidades de resolución alternativa a que se refiere art. 9.3.b).

${ }^{86}$ Conforme al art. 10 del Reglamento, la entidad de resolución alternativa de conflictos concluirá el procedimiento en el plazo de 90 días naturales a contar desde que recibió el expediente completo de la reclamación salvo si se niega a tramitar el litigio de acuerdo con el art. 5, apartado 4, de la Directiva 2013/11/UE.
} 
resolución alternativa de litigios no impedirá al consumidor, ya sea demandante o demandado, acogerse a la jurisdicción de los tribunales del Estado miembro en el que tenga su domicilio ${ }^{87}$.

\section{El futuro de las acciones colectivas en la UE}

23. Dadas las peculiares características presentes en la sociedad de la hiperproducción en que vivimos, sólo un sistema de alcance colectivo de acciones ejercitadas por entidades portadoras o representativas de los derechos e intereses existentes en el ámbito del consumo masivo de bienes y servicios garantiza una real efectividad de tales derechos e intereses. Si únicamente se previera el ejercicio de acciones individuales, dirigidas a que cada consumidor o usuario tratara de salvaguardar su posición jurídica singular en caso verse afectada por un hecho dañoso, se acabaría generando en la práctica una desprotección de aquéllos, dado que la escasa relevancia económica del daño no compensaría los costes de un proceso, al que, por tanto, dejaría de acudirse en multitud de ocasiones. De este modo, las acciones colectivas están dirigidas a tutelar los derechos e intereses pluriindividuales y/o supraindividuales de determinados grupos (como los consumidores y usuarios), cuando se puedan ver afectados por conductas antijurídicas o, según expresión legal frecuente, por «hechos dañosos» ${ }^{88}$. Por la naturaleza colectiva de la acción, es el propio legislador quien debe determinar a quién o quiénes atribuye su titularidad (legitimación). Por ello, en general, las leyes de los Estados no sólo reconocen la accionabilidad de pretensiones de carácter colectivo, sino que también incluyen listados en que se determinan las personas o entidades legitimadas para su ejercicio judicial. En el contexto de la UE, se ha regulado las acciones colectivas mediante la Directiva 2009/22/CE, de 23 de abril de 2009, "relativa a las acciones de cesación en materia de protección de los intereses de los consumidores". No obstante, el escaso contenido de esta norma ha conducido a la Comisión a emitir diversas recomendaciones al respecto, destacando especialmente la "Recomendación sobre los principios comunes aplicables a los mecanismos de recurso colectivo de cesación o de indemnización en los Estados miembros en caso de violación de los derechos reconocidos por el Derecho de la Unión”, de 11 de junio de 2013. Esta recomendación fue además objeto de Informe de la Comisión al Parlamento Europeo, al Consejo y al Comité Económico y Social Europeo, de 25 de enero de 2018. A raíz de este informe, la Comisión Europea adoptó el 11 de abril de 2018 un nuevo acuerdo con el fin de garantizar que todos los consumidores europeos se beneficien plenamente de sus derechos con arreglo al Derecho de la Unión ${ }^{89}$.

24. Fruto del íter que se acaba de exponer, nace finalmente la Directiva (UE) 2020/1828 del Parlamento Europeo y del Consejo, de 25 de noviembre de 2020, relativa a las acciones de representación para la protección de los intereses colectivos de los consumidores, y por la que se deroga la Directiva

${ }^{87}$ D. Carrizo Aguado, loc. cit., p. 68, apunta que tal posibilidad provoca un efecto preventivo, que contribuye a que el empresario actúe con mayor fidelidad a lo estipulado en el contrato, sin olvidar que la mayoría de las reclamaciones derivadas de la venta en línea de servicios turísticos no encuentran solución a través de la vía judicial.

${ }^{88}$ La Ley 1/2000, de 7 de enero, de Enjuiciamiento Civil, ha regulado por primera vez en el Derecho español el ejercicio procesal de acciones dirigidas a obtener una tutela de los intereses generales o supraindividuales de los consumidores y usuarios. Fuera ya de la LEC, también existen en algunos de los textos sustantivos de protección a los consumidores y usuarios antes enunciados normas de carácter procesal, aplicables a los litigios en que se sustancien controversias de naturaleza colectiva ( v.gr., normas sobre prueba en los arts. 26 y 28 LGDCU y en el art. 24 LSSI; sobre publicidad de sentencias, en el art. 21 LCGC o en el art. 31 LGP; sobre acumulación de acciones colectivas en el art. 16 LCGC). Tanto en la versión inicial de la LEC, como en las distintas leyes sustantivas, han incidido diversas directivas comunitarias, transpuestas al ordenamiento jurídico español a través de la Ley 39/2002, de 28 de octubre.

${ }^{89}$ Véase la propuesta del Parlamento Europeo y del Consejo, relativa a las acciones de representación para la protección de los intereses colectivos de los consumidores y por la que se deroga la Directiva 2009/22/CE [COM/2018/184 final - 2018/0089 (COD)]. No serán abordados aquí los problemas más típicos del Derecho internacional privado que plantean las acciones colectivas, puesto que ya han sido enfrentados en la que puede considerarse como obra de referencia en España, de L. CARBALLO PIÑEIro, Las acciones colectivas y su eficacia extraterritorial. Problemas de recepción y transplante de las class actions en europa, Colección De Conflicto Legum, Santiago de Compostela, Servicio de Publicaciones de la USC, 2009. De la misma autora se puede consultar asimismo "Acciones colectivas transfronterizas. Prospectiva de Derecho Internacional Privado europeo", Revista de Derecho privado y comunitario, 2011, pp. 585-617. 
2009/22/CE ${ }^{90}$. Las acciones de representación pueden iniciarse así en el supuesto de vulneraciones de un corpus jurídico mucho más amplio que el anterior incluyendo, entre otras, la legislación horizontal relativa a los consumidores y leyes sectoriales específicas de los ámbitos de los servicios financieros, la energía, las telecomunicaciones, los viajes y el turismo. Al igual que la Directiva sobre acciones de cesación, la Directiva 2020/1828 permite que las «entidades habilitadas» designadas por los EE.MM. interpongan acciones de representación, siempre que cumplan los criterios mínimos de reputación (art. 4.1 $\left.{ }^{\circ}\right)^{91}$. Los órganos jurisdiccionales y las autoridades administrativas estarán facultados para evaluar los acuerdos de financiación por parte de terceros (art. 10.3 $)$. La propuesta exigirá a los EE.MM. que garanticen una «diligencia debida» en los procedimientos (art. 17) y que eviten que las costas procesales se conviertan en un obstáculo económico para interponer acciones de representación (art. $20.1^{\circ}$ ). Se informará adecuadamente a los consumidores del resultado de las acciones de representación y de cómo se beneficiarán de estas (art. 13). La propuesta también favorece los acuerdos colectivos extrajudiciales, sin perjuicio del control del órgano jurisdiccional o de la autoridad administrativa (art. 11). Las resoluciones firmes de los órganos jurisdiccionales o autoridades administrativas de cualquier E.M., que declaren la existencia de una infracción que perjudique los intereses colectivos de los consumidores, podrán ser alegadas por todas las partes como prueba en el contexto de cualquier otra acción ante sus órganos jurisdiccionales o autoridades administrativas nacionales, para solicitar medidas resarcitorias contra el mismo empresario por la misma práctica (art. 15). Asimismo, se permite a las entidades habilitadas interponer acciones de representación para obtener diferentes tipos de medidas, según corresponda, dependiendo de las circunstancias del caso, que incluyen medidas cautelares o definitivas para que cese o se prohíba la práctica de un comerciante, si se considera una infracción de la ley, y medidas que eliminen los efectos continuados de la infracción. Estas últimas podrían incluir órdenes de reparación y resoluciones declarativas que determinen la responsabilidad del comerciante frente a los consumidores perjudicados por las infracciones. Habrá que aguardar todavía, con todo, para comprobar si, en palabras de la propia Comisión, con la Directiva se alcanza un modelo que consiga "el equilibrio entre facilitar el acceso a la justicia para proteger los intereses de los consumidores y garantizar las salvaguardias adecuadas frente a litigios abusivos" ${ }^{92}$.

\section{El procedimiento transfronterizo electrónico}

25. La Declaración Ministerial de Administración Electrónica de Malmö, de 2009, entendió, como uno de sus cuatro ejes prioritarios, que "la movilidad en el mercado único ha de ser reforzada por servicios integrados de administración electrónica para la creación y la gestión de empresas, para el estudio, el trabajo, la residencia y la jubilación en cualquier país de la Unión Europea" ${ }^{\text {93 }}$. Este acuerdo entre los máximos responsables de la Administración Electrónica (AE, desde ahora) de los EE.MM. supuso un espaldarazo definitivo a los servicios transfronterizos de AE dentro de la UE. El impulso al desarrollo de los mismos se consolidaría así en la denominada "Agenda Digital para Europa"94, así como en el "Plan de Acción de AE Europeo 2011-2015"95, que incluían ambos entre sus objetivos la disponibilidad en 2015 de un conjunto de servicios claves transfronterizos ${ }^{96}$. El ámbito de actuación de

\footnotetext{
${ }^{90}$ DOUE L/409, 4 diciembre 2020.

${ }^{91}$ Básicamente, los contenidos en el art. $4.3^{\circ}$ a) a e): estar debidamente constituidas conforme a la ley de un E.M., ser entidades sin ánimo de lucro ni estar incursas en procedimientos de insolvencia, independientes y tener un interés legítimo en proteger el interés de los consumidores según la legislación pertinente de la UE; debiendo además hacer público que cumplen tales requisitos, según el apartado $\mathrm{f}$ ).

92 En un plazo de tres años, la Comisión tendría que evaluar la necesidad de establecer un Defensor del Pueblo Europeo especializado en acciones de reparación colectivas.

93 Extraído de Observatorio de Administración Electrónica (Ministerio de Hacienda y Administraciones Públicas) "Los servicios de Administración Electrónica Transfronterizos. Haciendo Europa mediante el uso de tecnologías", documento Marzo 2012, (https://administracionelectronica.gob.es/pae_Home/dam/jcr:213798dd-0d13-43a5-bff9-3f61edc40585/Servicios_ Transfronterizos_0.2.pdf) lugar de donde derivan asimismo los desarrollos que siguen a continuación.

$94 \mathrm{http}$ ://ec.europa.eu/information_society/digital-agenda/index_en.htm.

$95 \mathrm{http}$ ://ec.europa.eu/information_society/activities/egovernment/action_plan_2011_2015/index_en.htm.

${ }^{96}$ El concepto de los servicios transfronterizos de AE no era novedoso cuando se alcanzó dicho acuerdo. Dentro de los
} 
los programas de promoción de la interoperabilidad se encontraba orientado a la creación de servicios e infraestructuras necesarios para la aplicación de actos y políticas comunitarios, la comunicación interinstitucional en la UE y el proceso de decisión comunitario; de manera que sus bases legales no proporcionaban los mecanismos necesarios para identificar, priorizar e impulsar servicios transfronterizos que a la postre requerían de una combinación de compromiso de los sectores afectados y de esfuerzo multilateral por parte de los EE.MM., lo que condujo a la Comisión Europea a establecer el mecanismo CIP (Programa de Competitividad e Innovación. Decisión 1639/2006/EC), que incluye una línea de actividad para impulsar el soporte de políticas públicas mediante las TIC (ICT PSP), al amparo de la cual se está avanzando en el desarrollo de pilotos de servicios transfronterizos, fuera del ámbito estricto de las competencias de la $\mathrm{UE}^{97}$. La construcción de los servicios transfronterizos de $\mathrm{AE}$ confirma lo profetizado en la Declaración Schumann en mayo de 1950: "Europa no se hará de una vez ni en una obra de conjunto: se hará gracias a realizaciones concretas, que creen en primer lugar una solidaridad de hecho". Estos programas piloto de gran tamaño, desarrollados en el marco del CIP, "son los primeros trazos de una colaboración multilateral entre los EE.MM. para construir la Europa digital, de geometría variable, pero que confluirá en los servicios clave que refuercen el mercado único y la movilidad de las personas" 98 .

26. Según un informe de la agencia Deloitte, casi tres millones y medio de litigios civiles y mercantiles han tenido repercusión transfronteriza en Europa ${ }^{99}$. Un marco jurídico del auxilio judicial internacional eficiente condiciona la manera en que la ciudadanía implicada en este tipo de causas percibe el funcionamiento del poder judicial y del Estado de Derecho en los EE.MM. Éste es el contexto en que cabe situar el compromiso de la Comisión, en su programa de trabajo para 2018, para elaborar propuestas de revisión del Reglamento sobre obtención de pruebas y, en lo que aquí concierne especialmente, del Re-

sucesivos programas de promoción de la interoperabilidad entre las Administraciones europeas (IDA, IDA II, IDABC), se habían alcanzado ya hitos importantes en cuanto al desarrollo tanto de servicios transfronterizos como de las infraestructuras horizontales necesarias para soportarlos. Así, por ejemplo, la Red TESTA que interconecta las Administraciones Públicas de la UE o el servicio europeo de empleo EURES, figuran entre los resultados de dichos programas, iniciados en 1995 (sobre el resultado de estos programas y el papel de España vid., "Los servicios públicos Europeos de Administración Electrónica: Programa ISA y estado de situación de la integración de la Administración”, informe disponible en http://administracionelectronica.gob.es/recursos/pae 020002227.pdf). El acuerdo técnico más importante surgido en este ámbito es el Marco Europeo de Interoperabilidad (disponible en la dirección de Internet http://administracionelectronica.gob.es/recursos/pae_000006268. pdf), surgido de los grupos de trabajo del más reciente programa ISA (Soluciones de Interoperabilidad para Administraciones Públicas, Decisión 922/2009/CE), bajo la forma jurídica de comunicación de la Comisión Europea.

${ }^{97}$ La lista de proyectos financiados mediante CIP -ICT PSP es ya extensa (un listado completo de los mismos se recoge en $\mathrm{http}$ ://ec.europa.eu/information_society/apps/projects/index.cfm?menu=secondary\&prog_id=IPSP). En ella la participación de Administraciones y empresas españolas es intensa, España es el segundo país más implicado en CIP ICT PSP tras Italia, alcanzando un $11 \%$ de peso en términos económicos 10 . Entre los proyectos financiados dentro de este programa destacan los pilotos de gran tamaño (LSP - Large Scale Pilots), que buscan involucrar a los interesados, como las autoridades públicas, proveedores de servicios y centros de investigación en toda la UE en la implementación de soluciones comunes para ofrecer servicios públicos en línea y hacerlos accesibles a través de Europa. Los 5 pilotos de gran tamaño ahora en desarrollo son los siguientes:

- e-CODEX11, destinado a mejorar el acceso transfronterizo de ciudadanos y empresas a los medios legales en Europa, así como para mejorar la interoperabilidad entre las autoridades judiciales en la UE.

- epSOS12, cuyo objetivo es diseñar, construir y evaluar una infraestructura de servicios que demuestra la interoperabilidad transfronteriza entre sistemas de historiales médicos electrónicos en la UE.

- PEPPOL13, que busca habilitar la integración transfronteriza de contratación electrónica, mediante la conexión de las comunidades de licitación pública a través de soluciones basadas en estándares.

- SPOCS14, establecido para construir la segunda generación de ventanillas única de la Directiva de Servicios a través de la disponibilidad en las mismas de procedimientos electrónicos de alto impacto.

- STORK15, dirigido a crear una plataforma europea de interoperabilidad identificación electrónica, que permitirá a la ciudadanía establecer nuevas relaciones electrónicas transfronterizas con sólo presentar su identificación electrónica nacional.

${ }^{98}$ Observatorio de AE, doc. cit. supra.

${ }^{99}$ Dichas estimaciones se basan en los datos de Eurostat, la Comisión Europea para la Eficacia de la Justicia (CEPEJ) del Consejo de Europa y la Comisión Europea, así como en la información recopilada durante las entrevistas realizadas al efecto. Se trata de una estimación para fundamentar la evaluación del impacto. 
glamento $1393 / 2007$, sobre notificación y traslado de documentos ${ }^{100}$. La evaluación de impacto ${ }^{101}$ llegó a la conclusión de que se derivarían ventajas de la utilización de las comunicaciones electrónicas para la digitalización del sistema judicial, mediante la simplificación y agilización de los procesos judiciales transfronterizos y la cooperación judicial; e indicó, en particular, dos modificaciones esenciales: la obligatoriedad de las comunicaciones electrónicas entre las agencias y la facilitación de la notificación y el traslado electrónicos; entendiendo que ambas contribuirían a aumentar la eficiencia y la rapidez de los procesos y reducirían la carga que soportan los ciudadanos y las empresas. También introduce una nueva medida que facilita el acceso a la notificación o traslado directos de documentos, ampliando el ámbito de aplicación del artículo 15 del Reglamento ${ }^{102}$. Asimismo, se espera aumentar la previsibilidad del procedimiento, modificando las disposiciones relativas a la obligación inexcusable de proporcionar la información sobre el derecho a negarse a aceptar un documento, mediante el formulario normalizado que figura en el anexo II, la ampliación del plazo para ejercitar el derecho de negarse a aceptar un documento y la clarificación del cometido del órgano jurisdiccional de origen en la evaluación de dicha negativa. Contribuyen a su vez al aumento de la seguridad jurídica las comprobaciones que deben realizar los órganos jurisdiccionales antes de dictar una sentencia en rebeldía, con arreglo al artículo 19 del Reglamento. Se entiende además que la propuesta no supondrá costes importantes para las administraciones nacionales, sino que, más bien, redundará en ahorros, dado que las autoridades públicas nacionales saldrán beneficiadas de la reducción de los costes por la notificación y traslado por correo, el ahorro de tiempo debido a la mayor eficiencia en los procesos judiciales y la reducción de la carga administrativa y los costes laborales ${ }^{103}$.

\section{Hacia un Derecho internacional privado híbrido, protector de intereses colectivos}

\section{La protección de los bienes culturales}

27. Los problemas relativos al tráfico internacional de bienes culturales son una cuestión de interés global, que afectan tanto al individuo como al colectivo y donde confluyen una pluralidad de intereses: de una parte, de los Estados que, dependiendo de su consideración como importadores o exportadores de arte, perseguirán la liberalización o la intervención en el mercado del arte, desde un nacionalismo cultural ${ }^{104}$. De otra parte, de los particulares, tanto compradores como vendedores, que

\footnotetext{
${ }^{100}$ Programa de trabajo de la Comisión para 2018: "Un Programa para una Europa más unida, más fuerte y más democrática" [COM(2017) 650 final], de 24.10.2017, anexo II, puntos 10 y 11. la aplicación del Reglamento ha sido objeto de evaluaciones pormenorizadas en los últimos años en estudios e informes de la Comisión y en los debates entablados en la Red Judicial Europea, figurando un listado exhaustivo de los mismos el informe anexo (8) a la evaluación de impacto adjunta a la propuesta de la Comisión [SWD(2018) 287 final], pp. 11-15. Además, la Comisión ha llevado a cabo una amplia consulta de las partes interesadas: del 8 de diciembre de 2017 al 2 de marzo de 2018 se llevó a cabo una consulta pública que abarcó tanto el Reglamento (CE) n. ${ }^{\circ}$ 1393/2007 como el Reglamento (CE) n. ${ }^{\circ}$ 1206/2001, recibiendo un total de 131 contribuciones (principalmente de Polonia, seguida de Alemania, Hungría y Grecia). Dos reuniones sobre el tema de la Red Judicial Europea trataron los problemas prácticos y las mejoras posibles, tanto del Reglamento sobre notificación y traslado de documentos como del Reglamento sobre la obtención de pruebas. Asimismo, se organizó una reunión específica con los expertos gubernamentales de los EE.MM. el 4 de mayo de 2018. El 16 de abril de 2018 se celebró un taller compuesto por las partes interesadas seleccionadas por su especial interés en los asuntos relativos a las causas judiciales transfronterizas. Además, el grupo de expertos sobre la modernización de la cooperación judicial en materia civil y mercantil celebro seis reuniones entre enero y mayo de 2018 y se llevaron a cabo dos estudios jurídicos comparativos extensos sobre la normativas y las prácticas de los EE.MM. en materia de notificación y traslado de documentos a fin de detectar los problemas que puedan surgir en la aplicación del Reglamento.

${ }^{101}$ Presente en el documento de trabajo de los servicios de la Comisión [SWD(2018) 287]. El Comité de Control Reglamentario revisó el proyecto de evaluación de impacto en una reunión celebrada el 3 de mayo de 2018 y emitió un dictamen favorable con observaciones el 7 de mayo de 2018, que a su vez tuvo en cuenta la DG de Justicia.

${ }^{102} \mathrm{Al}$ permitir que a) los organismos transmisores y b) los órganos jurisdiccionales que conozcan del asunto en el E.M. de origen y en el territorio de todos los EE.MM. puedan notificar o trasladar directamente los documentos, la transmisión de estos sería más directa y rápida.

${ }^{103}$ La propuesta, tras ser votada favorablemente en el Parlamento Europeo el 13 de febrero de 2019, ha sido objeto de 14 debates en el Consejo desde el 6 de junio de 2018 hasta el 7 de febrero de 2020.

${ }^{104}$ B. L. Carrillo Carrillo, "Tráfico internacional ilícito de bienes culturales y derecho internacional privado", Anales de Derecho de la Universidad de Murcia, 2001, pp. 205-334
} 
buscan también el establecimiento de un libre mercado, desde un internacionalismo cultural ${ }^{105}$, frente al del poseedor de buena fe de un bien cultural exportado ilegalmente o al del propietario desposeído, que buscan su satisfacción. Por último, cabe mencionar también el interés general en la preservación del patrimonio cultural de la humanidad ${ }^{106}$. En este marco, se insertan tanto la Directiva 2014/60/UE, de 15 de mayo de $2014^{107}$ como su norma de transposición al ordenamiento español, la Ley $1 / 2017^{108}$, de 18 de abril. La Directiva delimita su ámbito objetivo en relación con la restitución de los bienes culturales, parte de un patrimonio nacional, que hayan abandonado su país de forma ilícita. El legislador español, por su parte, realiza un desglose de la escueta redacción comunitaria, recogiendo las condiciones para la restitución de un bien cultural que se encuentre en otro E.M. de la UE por su salida ilegal y también la situación opuesta (la acción de restitución sobre un bien cultural de otro E.M.) que se encuentre en nuestro territorio y de la que conocerán nuestras autoridades ${ }^{109}$. De este modo, el artículo segundo de la Directiva recoge un listado de definiciones para delimitar el ámbito tanto subjetivo como objetivo de la norma ${ }^{110}$,

${ }^{105}$ L. Pérez-Prat Durbán, “Las vicisitudes del patrimonio cultural: arte y derecho” en Cursos de Derecho Internacional y Relaciones Internacionales de Vitoria Gasteiz de 2006, Vitoria, 2007, pp. 240-270.

${ }^{106}$ No existe un concepto general y comúnmente aceptado de "patrimonio cultural" o siquiera de "bien cultural". Si bien es cierto que todos los instrumentos normativos contemplan definiciones de manera más o menos completa y exhaustiva, las mismas solo definen el concepto en función del ámbito de protección jurídica que pretenden otorgarle, pero en ningún texto se proporciona una noción que aúne todas las características globales de un "bien cultural", dado que cada cuerpo legal adopta el concepto más ajustado al fin concreto que persigue. Existen, por tanto, diversas tesis respecto a su clasificación: desde una perspectiva maximalista (E. R. HARVEY, Relaciones culturales internacionales en Iberoamérica y el mundo, Tecnos, Madrid, 1991, pp. 251-252) que parte de la definición del concepto de "cultura", un bien cultural sería aquel que "referencia a la historia en su más amplio sentido, historia comprensiva de todas las facetas o aspectos del actuar humano" (C. BARRERO RoDríGUEZ, $L a$ ordenación jurídica del patrimonio histórico, Universidad de Sevilla, Civitas, Madrid, 1990, p. 116) o historia de la civilización (M. S. GiAnNI, "I beni culturali", Rivista trimestrale di diritto pubblico, vol. LXXVI, nº 1, 1976, p. 6) debiendo servir de testimonio de una cultura anterior, de un suceso histórico o de la evolución. Desde una perspectiva minimalista (como sucede con la Convención Europea sobre las infracciones relativas a los bienes culturales, de 23 de junio de 1985) el status de bien cultural lo tendrían aquellas obras cuyo valor cultural se haya reconocido por su importancia excepcional en el país del que se trate. Finalmente, desde una perspectiva descriptiva, propia de los países del common law, se entenderá por bien cultural aquel que haya sido calificado como tal por una autoridad competente en un momento determinado, en un Estado determinado. De este modo, las definiciones parecen limitarse al patrimonio arquitectónico y arqueológico, privilegiando el aspecto material o físico de estos bienes en la sociedad, olvidando la cuestión clave de las funciones diversas que cumplen los bienes culturales en la sociedad contemporánea (N. CAMPS MIRABET, La protección internacional del patrimonio cultural, Universidad de Lleida, 2000 , p.113). No obstante, cabe afirmar que, independientemente del criterio adoptado para definir lo que es un "bien cultural", éste es un concepto formal que constituye una categoría jurídica plenamente aceptada en el Derecho Internacional Contemporáneo, especialmente, a partir de la segunda guerra mundial (Ibid., p. 111)

${ }^{107}$ Del Parlamento Europeo y del Consejo, relativa a la restitución de bienes culturales que hayan salido de forma ilegal del territorio de un Estado miembro (DOUE L/159, 28 de mayo de 2014).

${ }^{108}$ Sobre restitución de bienes culturales que hayan salido de forma ilegal de territorio español o del de otro E.M. de la Unión Europea, por la que se incorpora al ordenamiento español la Directiva 2014/60/UE, del Parlamento Europeo y del Consejo, de 15 de mayo de 2014 (BOE núm. 93, de 19 de Abril de 2017).

${ }^{109}$ Este precepto supone una de las principales innovaciones frente a la regulación anterior, donde la delimitación del objeto era mucho más estricta pues, aparte de referirse únicamente a bienes culturales que tuviesen el reconocimiento de patrimonio nacional, debía de tratarse piezas reconocidas en su anexo, donde establecía un numerus clausus de posibilidades que dejaba fuera en la práctica a otros bienes que ciertamente pudiesen tener valor cultural o artístico, amén de otras restricciones como un umbral de antigüedad o de valor económico que las obras habrían de superar para que la norma desplegase sus efectos protectores sobre ellas (vid. Directiva 93/7/CEE, del Consejo, de 15 de marzo de 1993, relativa a la restitución de bienes culturales que hayan salido de forma ilegal del territorio de un Estado miembro, transpuesta en España por la Ley 36/1994, de 23 de diciembre). Además, la propia Directiva 2014/60 recoge la posibilidad de ser aplicada a bienes culturales distintos de los definidos en su texto $\left(\operatorname{art} .15 .1^{\circ}\right)$, incluyendo tácitamente un numerus apertus que expresa el refuerzo del carácter protector que se le intenta dar a la norma.

110 Tanto en la Directiva como en la ley española se recoge la definición de bien cultural, el que esté clasificado como «patrimonio artístico, histórico o cultural», con arreglo a la legislación o a procedimientos administrativos nacionales en el marco del artículo 36 TFUE, (importante matiz temporal, al indicar que la clasificación es independiente del momento de salida del bien cultural del territorio del Estado del que es patrimonio). En virtud del artículo 15.1 de la Directiva -que recoge la posibilidad de aplicarla a otros bienes que no encajen en la definición del precepto del artículo $2.1^{\circ}$ - el legislador español introduce el texto del artículo 2.1.b. protegiendo, como recoge en su Preámbulo "bienes de valor histórico, paleontológico, etnográfico, numismático y científico"; ampliando así el concepto de bien cultural para abarcar otros bienes que sin ser propiedad del Estado puedan beneficiarse de esta protección por su importancia histórico-artística, como los de las instituciones eclesiásticas, colecciones públicas y aquellos que se encuentren incluidos tanto en la Ley de Patrimonio Histórico Español y en las leyes autonómicas de patrimonio, como en el reglamento del Consejo Europeo relativo a la exportación de bienes culturales, bien públicos o privados. 
expresando además en su artículo 3 que la restitución de los bienes que hayan salido ilícitamente de un E.M. se regirá por la Directiva y el procedimiento en ella recogido, siendo una de las principales innovaciones que incluye (artículo 4) la necesidad de crear una autoridad central única, en cada E.M., con competencias propias en esta materia (artículo 5) entre las que se incluirían: la localización de un bien cultural determinado por petición del Estado requirente, la notificación a otros EE.MM. del hallazgo de bienes culturales presuntamente ilícitos en su territorio, ayudar a la verificación de estos mismos en un plazo de seis meses desde la notificación, la adopción de medidas para la conservación del bien cultural y para evitar que no se aplique el procedimiento de restitución y su actuación como intermediario en ciertas ocasiones, como en el procedimiento arbitral ${ }^{111}$. La piedra angular del sistema es la acción de restitución del bien cultural que el E.M. requirente podrá interponer contra el poseedor y, en su defecto, contra el tenedor, ante los tribunales competentes del E.M. requerido, cuando dicho bien hubiera salido de forma ilegal de su territorio (artículo 6).

28. La explotación de pueblos y territorios puede conducir al comercio ilícito de bienes culturales, en particular, cuando tiene su origen en un contexto de conflicto armado. La apropiación de bienes del Patrimonio artístico, arqueológico o histórico sin consentimiento de las autoridades del Estado propietario del bien ni observancia de las normas de protección de bienes culturales (que se conoce como "expolio") es una práctica muy antigua ${ }^{112}$. La UE es consciente de que deben adoptarse normas comunes sobre el comercio con terceros países a fin de garantizar la protección eficaz contra el comercio ilícito de bienes culturales, así como contra su pérdida o destrucción, la conservación del patrimonio cultural de la humanidad y la prevención de la financiación del terrorismo y el blanqueo de capitales a través de la venta a compradores en la Unión de bienes culturales saqueados ${ }^{113}$. De este modo, el Reglamento establece "las condiciones

${ }^{111}$ Nuestra norma de transposición reúne todo esto de manera casi literal en un único artículo (el tercero) y nombra como Autoridad Central Competente a la Secretaría de Estado de Cultura, sin perjuicio de que en el punto 3.3 se aluda al Consejo de Patrimonio Histórico Español como mediador entre los órganos de las comunidades autónomas y la administración general. El medio que la Directiva aporta para que las autoridades centrales de los Estados puedan desempeñar tales funciones y mantener una comunicación más estrecha que redunde en una mejor cooperación entre ellas es el IMI, el Sistema de Información del Mercado Interior (artículo 7). La ley española aúna estas menciones en su artículo 4.

${ }^{112}$ El primer expolio documentado aconteció en el siglo XII a.C., en Egipto, a cargo de Paweera, monarca (alcalde) de la ribera occidental de Tebas, donde se situaban las tumbas del Valle de los Reyes, que fue acusado por Paser, su homólogo de la orilla oriental (J. A. MARTós, "El expolio del mundo antiguo: Saqueadores del pasado", Muy Historia, no 63, Mayo 2015, p. 20). Históricamente, el expolio se ha ido configurando como un ius predae, del vencedor sobre el vencido (C. M. CAAMIÑA DomínGUEz, "La protección internacional de los bienes culturales en tiempos de guerra", en A. L. Calvo Caravaca y S. Areal LudeÑa (Coords.), Cuestiones actuales de Derecho Mercantil Internacional, Colex. Madrid, 2005, p. 131) como modo de sufragar parte de las pérdidas tanto económicas como personales ocasionadas por la guerra. Desde el siglo XII a.C. hasta el fin de la Edad Media es una práctica que se repite en cualquier conflicto armado, indistintamente del Estado de origen o de la religión que practicase el vencedor. Célebre es el caso de las campanas de la Catedral de Santiago, robadas por el caudillo musulmán Almanzor en el año 997, y trasladadas hasta Córdoba, capital del califato, para ser devueltas a su iglesia de origen con la reconquista, dos siglos después. A partir de 1527, con el Saco di Roma, en pleno Renacimiento, se comenzó a apreciar el valor cultural de las obras expoliadas con esta práctica. En este mismo siglo, a consecuencia del descubrimiento de América, comienza una nueva fase, caracterizada por una apropiación auspiciada y legitimada por los propios Estados, independiente de las conquistas bélicas, basada en el colonialismo y el expolio de la riqueza de los pueblos autóctonos, que las naciones europeas van a utilizar de forma agresiva. Este cambio de paradigma llegará a revestir importantes consecuencias políticas, económicas e, incluso, jurídicas. Así, el expolio llevado a cabo por orden del Zar Iván el Terrible sobre la artesanía peletera de los pueblos de Siberia, que acabó derivando en una invasión de sus tierras, convirtió a Rusia en el territorio más grande del planeta, iniciando su carrera como potencia mundial. Por otro lado, las actuaciones de la Compañía Holandesa de las Indias Orientales sobre los recursos de los pueblos colonizados avanzaron la instauración del capitalismo moderno, pues el ingente patrimonio amasado acabó convirtiéndola en la primera empresa cotizada, mediante la creación de la primera bolsa de valores, en 1608. Leyenda negra española, aparte.

${ }^{113}$ Tal vez estas buenas intenciones sean fruto de un examen de conciencia, mirando hacia la Historia moderna y contemporánea de los propios países europeos. Durante el S.XVIII -en parte gracias a los principios de la Ilustración, en parte a los valores del Neoclasicismo- surgió un fervor por la arqueología que, consecuentemente, impulsó la realización de excavaciones, como es el caso de Herculano (1738) y Pompeya (1746) que -aparte del fin del conocimiento mejor de la cultura romana- contaba con el de la obtención de piezas artísticas de esa época. Si bien la sociedad del momento estaba configurada de otra manera (existía una burguesía influenciada por el arte neoclásico, con pretensiones cosmopolitas, que veía en el mercado de antigüedades el potencial para una mejor consideración social) el coleccionismo se extendió a todos los rincones, impulsando la creación de los museos. Espacios como el British Museum (1753) o el Museo del Louvre (1793) serán los cooperadores necesarios para nuevas adueñaciones al margen de la legalidad y del rigor arqueológico. La llegada al poder de Napoleón Bonaparte -que in- 
para la introducción de bienes culturales y las condiciones y procedimientos para la importación de bienes culturales con fines de salvaguardia del patrimonio cultural de la humanidad y de prevención del comercio ilícito de bienes culturales, en particular en los casos en los que dicho comercio ilícito pueda contribuir a la financiación del terrorismo" (artículo 1). En consecuencia, la UE prohíbe la introducción en su territorio aduanero de bienes culturales exportados ilícitamente desde terceros países, "prestando especial atención a los bienes culturales procedentes de terceros países afectados por conflictos armados, en particular cuando dichos bienes culturales hayan sido objeto de comercio ilícito por parte de organizaciones terroristas $\mathrm{u}$ otro tipo de organizaciones criminales" ${ }^{\prime 14}$. Se establece al efecto, mediante el Reglamento 2019/880, un sistema

vadió territorios con el pretexto del mejor conocimiento de su cultura ancestral, siguiendo principios ilustrados (como Egipto e Irak)- confirmó un nuevo sistema de expolio, pues las diferentes naciones acaparadoras de bienes culturales de otros territorios habían llegado a una conclusión después del saqueo de América: la debilidad e inestabilidad política de un país propiciaba el latrocinio cultural. Así, por ejemplo, durante el S.XIX se realizaron excavaciones y usurpaciones aprovechándose de la precaria situación de los países que formaban parte del imperio otomano y se encontraban en una deficiente situación geopolítica. Hay ejemplos muy conocidos y otros menos:

- En 1790, el artista Thomas Jenkins se percató de que el comercio de antigüedades artísticas era más rentable que su propia profesión, por lo que decidió dedicarse a la extracción y venta masiva de éstas: el Discóbolo de la Villa Adriana de Tívoli, acabó en el British Museum, merced a sus servicios, que también empleó en el caso de la Venus Barberini

- En 1801, Thomas Bruce, conde de Elgin, amante de la arqueología griega, consiguió una orden personal del sultán otomano para poder llevarse cualquier pieza de piedra del Partenón, bajo el pretexto de la protección de las mismas frente a la desatención de los turcos, por lo que decidió llevarse los mármoles a su casa, en Reino Unido. Las deudas que le ocasionaron las excavaciones y los sobornos a diferentes autoridades hicieron que acabase vendiéndoselos al Estado, pasando así a formar parte de la colección del British Museum. Los Mármoles de Elgin suponen un 37,5\% de los frisos del Partenón, aparte de otras figuras y esculturas robadas, como las piezas del templo de Atenea Niké, o incluso una columna y una cariátide del Erecteión.

- Tras la campaña francesa en Egipto (1801), con muchos bienes pendientes de ser enviados a Francia, los británicos cercaron a los franceses haciéndose, entre otros, con la Piedra Rosetta, clave para descrifrar los jeroglíficos por R. CHAMPOLION, trasladándola hasta el British Museum donde permanece hasta hoy, siendo una de sus pieza más visitadas.

- Henri Schliemann, millonario prusiano apasionado de la arqueología, dedicó su vida a demostrar que los relatos homéricos se basaban en escenarios históricos reales, atribuyéndosele el descubrimiento de la antigua Troya. En tal búsqueda, al carecer de preparación, propició la destrucción de otros estratos posteriores, perdiendo así valiosísima información histórica y cultural. En 1873, se hizo con el llamado "Tesoro de Príamo" y, sin permiso del sultán otomano, lo transportó a Grecia, enfureciendo a las autoridades turcas, que decidieron llevarlo ante los tribunales griegos, siendo el primer caso de confrontación internacional por restos arqueológicos. El Tribunal falló en favor del imperio otomano obligando a Schliemann al pago de una multa al Museo de Constantinopla (paradójicamente no se obligó a la devolución de las piezas, que hoy en día se encuentran en Rusia).

- El Altar de Pérgamo, como indica su nombre, es una construcción parte de un templo cumbre del estilo escultórico helenístico. Fue trasladado a Berlín en 1886, donde pasó a formar parte de la colección del Museo de Pérgamo.

- En 1901, JACQUES DE MoRgan encontraría en una excavación realizada en Irán, antigua Mesopotamia, una estela de diorita de 2,25 metros de alto con inscripciones a su alrededor, y decidió llevársela a su país, para que fuese objeto de estudio y traducción. Una vez en Francia, se dedujo que se trataba del Código de Hammurabi (actualmente, en el Museo del Louvre).

- Entre 1902 y 1914, Alemania propició expediciones arqueológicas, entre ellas excavaciones, en los que era la antigua Babilonia, muy próxima a Bagdad, descubriendo los restos de las puertas de las murallas que guardaban la ciudad, que fueron trasladadas a Berlín, para su reconstrucción, donde actualmente se exhiben. Su pieza principal es la puerta de Ishtar, realizada en lapislázuli.

- En 1913, el arqueólogo Ludwig BucKhart se hace con el busto de Nefertiti, engañando a las autoridades egipcias y consigue llevarlo hasta Berlín, donde se encuentra actualmente.

- Finalmente, en España, destaca el expolio realizado por las tropas napoleónicas en su invasión, llevándose consigo gran parte de la pintura barroca española y flamenca. En el transporte de estas obras a Francia, el general inglés WeLLINGTON interceptó la caravana que había salido del Palacio Real de Madrid, contactando con el rey FerNANDo VII, con intención de devolverla, quien decidió que se las quedara. Por otra parte, a principios del s. XX, el magnate estadounidense WiLLIAM RANDOLPH HEARST se hizo con la reja de la Catedral de Valladolid, que tuvo que vender para una recuperación económica, y hoy en día se encuentra en el Metropolitan Museum de Nueva York. Suerte parecida corrió el Monasterio de Sacramenia, comprado por él y llevado piedra a piedra a Miami, si bien tuvo que deshacerse de su propiedad con el mismo fin.

114 Tal y como se aclara en el considerando tercero del Reglamento, donde también se señala que "mientras sea posible participar en un comercio lucrativo de bienes culturales excavados ilícitamente y obtener beneficios de dicho comercio sin grandes riesgos, tales excavaciones y saqueos seguirán produciéndose. Debido a su valor económico y artístico, los bienes culturales acusan una fuerte demanda en el mercado internacional. La ausencia de medidas jurídicas internacionales firmes y la ineficaz aplicación de las medidas existentes dan lugar a que estos bienes pasen a la economía sumergida". En este sentido, la solución adoptada se encuentra dentro de una filosofía semejante a la que preside el denominado "Proceso Kimberley", sobre el 
de licencias de importación (regulada en el artículo 4; expedida por la autoridad competente del Estado miembro en el que los bienes culturales se incluyan por primera vez en uno de los regímenes aduaneros a los que se refiere el artículo 2, punto 3) o de declaración del importador (regulada en el artículo 5). El instrumento a elegir dependerá del tipo de bien (los que figuran en el anexo B, para las primeras; los del anexo C, para las segundas), que se deberán facilitar a las autoridades aduaneras facultadas (artículo $3.2^{\circ}$ ), las cuales podrán limitarse en número (artículo 6), debiendo cooperar entre ellas (artículo 7), así como con las autoridades competentes de los EE.MM. señaladas en el artículo 4. Con ello se pretende, en suma, "garantizar que determinadas importaciones de bienes culturales sean sometidas a controles uniformes en el momento de su entrada en el territorio aduanero de la Unión, sobre la base de los procesos, procedimientos e instrumentos administrativos existentes" (considerando 4).

\section{La protección internacional de los recursos genéticos}

29. Según el artículo $2.10^{\circ}$ del Convenio de Diversidad Biológica (CDB) ${ }^{115}$, un "recurso genético" es "aquella materia de origen animal, vegetal, o microbiano, que contiene información genética y que tiene importancia real o potencial". Estos recursos suponen actualmente no solo una fuente de innovación científica, sino también de explotación industrial. El Protocolo de Nagoya surge como instrumento jurídicamente vinculante para tratar de paliar las carencias acumuladas del CDB (particularmente, en cuanto a su tercer objetivo, relativo a la participación justa y equitativa en los beneficios) y las denominadas "Directrices de Bonn" ${ }^{116}$. El Protocolo afina tanto la regulación de acceso a los recursos como obligaciones generales de participación en beneficios (artículo 1), profundizando así en la protección otorgada a los recursos genéticos contenida en el artículo 15 del CDB (artículo 3 de Nagoya) ${ }^{117}$. Para determinar si se activa o no este mecanismo de protección (cuestión que en todo caso queda al arbitrio de las Partes, que pueden decidir en qué casos se activa), será crucial el propósito que tenga el acceso a los recursos genéticos, con tres posibilidades: primera (excluida del ámbito del Protocolo), que dicho acceso tenga como objetivo emplear un determinado recurso como materia prima; segunda, que

tráfico ilícito de diamantes (cuestión que ha sido abordada en profundidad en nuestra doctrina por P. DiAGo DiAGO, "El comercio internacional de diamantes: sistema de certificación del Proceso Kimberley", Cuadernos de Derecho Transnacional, marzo de 2009, vol. 1/1, pp. 72-91; id., "Los diamantes de conflicto y el comercio internacional: necesaria evolución del sistema de certificación del proceso Kimberley (PK)”, Diario La Ley, no 8364, 2014).

${ }^{115}$ Adoptado en mayo de 1992, en Nairobi, tras una compleja negociación en el seno del Programa de las Naciones Unidas para el Medio Ambiente (PNUMA). En junio de 1992 se abrió para su firma, durante la Conferencia de Naciones Unidas sobre Medio Ambiente y Desarrollo en Río de Janeiro, entrando en vigor el 29 de diciembre de 1993. En la actualidad, son parte en el mismo 195 Estados y la UE, en su conjunto (lista de EE.MM. del Convenio en https://www.cbd.int/information/parties.shtml). Como ausencia significativa cabe destacar a los EE.UU., que lo firmó bajo la administración Clinton pero se ha negado a ratificarlo, justificando su decisión alegando en el acta final de Nairobi un insatisfactorio tratamiento de la regulación de propiedad intelectual (vid. texto de la Declaración en International Law Magazine, 1992, vol. 31, p. 848).

${ }^{116}$ El CDB revolucionó la concepción jurídica de la protección de los recursos biológicos y, en particular, de los genéticos; pero contaba con una aplicabilidad limitada que se puso de manifiesto, por ejemplo, en la negativa de los Estados Unidos a formar parte del mismo. En este contexto, la Conferencia de las Partes estableció un grupo de trabajo de composición abierta sobre acceso y distribución de beneficios, con el objetivo de elaborar directrices para ayudar a la implantación del Convenio, sobre todo en lo que respecta a sus disposiciones sobre acceso y distribución de beneficios. Fruto de la labor de dicho grupo de trabajo son las Directrices de Bonn, aprobadas por la Conferencia de las Partes en abril de 2002. No es un instrumento vinculante, pero está diseñado para ser ampliamente aceptado por las Partes (han sido adoptadas unánimemente por 180 países, si bien con críticas, particularmente por los países en desarrollo, a su falta de obligatoriedad), pudiendo considerarse normas de soft law especializadas en la regulación internacional de acceso a recursos genéticos (M. Melgar Fernández, Las relaciones entre los regímenes de la biodiversidad y la propiedad intelectual en el Derecho Internacional Contemporáneo: un enfoque integrado, Tesis Doctoral, Universitat Pompeu Fabra, Barcelona 2003, p. 114).

${ }^{117}$ Si bien el Protocolo expande la definición de "recurso genético" para incluir ciertos compuestos bioquímicos; además, también se acota la referencia al "uso de recursos genéticos", ya que se especifica que los mecanismos del Protocolo solamente se activarán cuando el acceso tiene fines de desarrollo, investigación o innovación sobre el material genético o los compuestos bioquímicos (artículo 2.c.). Por la Decisión CDB 2/11, “Acceso a recursos genéticos”, de 30 de noviembre de 1995, ya se había acordado excluir del CDB los recursos genéticos humanos. Por su parte, Nagoya no ha sido un instrumento jurídico fácil de acordar, tomando seis años las negociaciones y nueve reuniones del grupo de trabajo, con la asistencia de cuatro grupos de expertos adicionales; el texto final fue acordado el 30 de octubre de 2010. 
tenga como objetivo el acceso a genoma para su aprovechamiento posterior (situación más claramente prevista en el Protocolo); y tercera, que se pretenda acceder al genoma, por propósitos de investigación básica. Dichos escenarios deberán ser examinados por la autoridad competente para activar las medidas correspondientes. Por otra parte, el artículo 8 obliga a las Partes a atenuar las disposiciones de acceso a recursos en relación con la investigación no comercial, en casos de emergencia relacionados con salud humana, animal o vegetal, así como para el acceso a recursos aplicados a la alimentación y la agricultura ${ }^{118}$. Además, el artículo $5.1^{\circ}$ establece la obligación (heredada del CDB y de Bonn, aunque aquí con carácter imperativo) de repartir los beneficios derivados del uso de recursos genéticos y de aplicaciones subsecuentes, así como de su comercialización, de forma justa y equitativa con la parte que los aporte; examinando en particular la situación de las comunidades indígenas en relación a los recursos genéticos y a conocimientos tradicionales asociados a los mismos ${ }^{119}$. Finalmente, los artículos 15 a 18 incluyen una serie de previsiones de cumplimiento normativo que suponen la mayor innovación introducida por el Protocolo, ya que es de los pocos aspectos completamente nuevos respecto del CDB o las Directrices de Bonn. Responden las dificultades de países proveedores de recursos (suelen ser países en desarrollo) para prevenir, detectar y remediar vulneraciones de sus medidas internas en tal ámbito ${ }^{120}$.

30. Para poder conjugar adecuadamente los intereses contrapuestos en relación con el derecho de acceso y el oportuno reparto de beneficios entre el titular del recurso y el interesado en su explotación cobra especial relevancia, en el marco del Protocolo, el necesario acuerdo mutuo entre ambas partes, donde se fijarán las distintas condiciones que van a regular con mayor detalle esos dos aspectos centrales. En tanto se deja cierta libertad a las partes, con independencia del modelo legal o puramente contractual que se siga, nos encontramos de lleno en el ámbito del Derecho privado; y, al tratarse además, por lo general, de relaciones con elemento extranjero, cobran especial relevancia los mecanismos propios del Derecho internacional privado que, en concreto, se fijan en el artículo $18^{121}$. Si atendemos a su contenido, este artículo parece inspirado en el principio de reconocimiento mutuo presente en la regulación de la cooperación internacional en materia de asuntos civiles transfronterizos del artículo 81 TFUE. Regresamos de nuevo entonces a la dialéctica entre el principio del país de origen y el principio del país de recepción, como regla general subsidiaria respecto de la autonomía de la voluntad. Sobre todo, si consideramos que se trata de permitir el acceso, por parte de un Estado, a los recursos genéticos existentes en su territorio, donde se encuentra el origen de los mismos. Asimismo, cabe destacar que los redactores del Protocolo parecen asumir un modelo contractual como dominante, en detrimento del legal, al no establecer una obligación para que los EE.MM. regulen los aspectos relativos al Derecho

${ }^{118}$ T. GreiBer y otros, Guía Explicativa del Protocolo de Nagoya sobre Acceso y Participación en los Beneficios, Gland (Suiza), UICN, 2013, p. 114.

${ }^{119}$ El Protocolo es novedoso a la hora de considerar, de forma amplia, los derechos de las comunidades indígenas y locales a la hora de explotar recursos genéticos relacionados con sus conocimientos tradicionales. De acuerdo con su artículo $5.2^{\circ}$, las Partes deben tomar medidas políticas, legales y administrativas que aseguren que los beneficios derivados del uso de estos conocimientos sean repartidos de modo justo e igualitario con las comunidades indígenas y locales que los apliquen. Esta es una obligación importante para dar cumplimiento a algunos de los objetivos del CDB (por ejemplo, su artículo $15.7^{\circ}$ ).

${ }^{120}$ En líneas generales, el artículo 15 se aplica a situaciones en que se accedió a un recurso genético sin respetar la legislación interna sobre consentimiento informado y condiciones mutuamente acordadas; mientras que el 16, con un enfoque similar, entrará en juego cuando la legislación vulnerada afecte a normativa de acceso a conocimientos tradicionales; el artículo 17 establece medidas de vigilancia y supervisión, así como, en particular, la designación de puntos de verificación; por último, el artículo 14, si bien no está incluido en este grupo de normas, crea un mecanismo de intercambio de información que facilita la aplicabilidad del Protocolo en general, y de los artículos 15 a 18, en particular.

121 “ 1 . Al aplicar el párrafo $3 \mathrm{~g}$ ) i) del artículo 6 y el artículo 7, cada Parte alentará a los proveedores y usuarios de recursos genéticos y/o conocimientos tradicionales asociados a recursos genéticos a que incluyan en las condiciones mutuamente acordadas, según proceda, disposiciones sobre resolución de controversias que abarquen: (a) La jurisdicción a la que se someterán todos los procesos de resolución de controversias; (b) La ley aplicable; y/u (c) Opciones para la resolución de controversias alternativa, tales como mediación o arbitraje. 2. Cada Parte se asegurará de que sus sistemas jurídicos ofrezcan la posibilidad de presentar recursos, de conformidad con los requisitos jurisdiccionales correspondientes, en casos de controversias dimanantes de las condiciones mutuamente acordadas. 3. Cada Parte adoptará medidas efectivas, según proceda, respecto a: (a) Acceso a la justicia; y (b) La utilización de mecanismos respecto al reconocimiento mutuo y la aplicación de sentencias extranjeras y laudos arbitrales. 4. La Conferencia de las Partes que actúa como reunión de las Partes en el presente Protocolo examinará la eficacia de este artículo conforme al artículo 31 del presente Protocolo". 
internacional privado, empleándose el verbo "alentar" y dirigiéndose a las partes para que contemplen tales aspectos dentro de "las condiciones mutuamente acordadas" (lo que no impide, obviamente, que cualquier Estado pueda adoptar una normativa propia al respecto). En suma, proveedores y usuarios de los recursos genéticos serán libres de acordar las condiciones que estimen oportunas, incluyendo entre ellas los aspectos de Derecho internacional privado, por lo que los problemas relativos a tal regulación deberán examinarse a la luz del modelo elegido en cada Estado ${ }^{122}$.

31. En el Derecho internacional actual, la discusión sobre ciencia gira en su mayor parte en torno a la gobernanza y diplomacia científicas, más que reflexionar sobre los derechos humanos que, sin embargo, incluyen el derecho a "disfrutar de los beneficios del progreso científico y sus aplicaciones" (artículo $15.1^{\circ} . \mathrm{b}$ del Pacto Internacional de Derechos Económicos, Sociales y Culturales o PIDESC). De ahí que, durante su sesión de febrero de 2020, el Comité de Derechos Económicos, Sociales y Culturales (CESCR) de la ONU haya adoptado un nuevo Comentario General (CG 25) sobre la relación entre la ciencia y los derechos económicos, sociales y culturales (DESC), centrándose precisamente en dicho artículo 15.1.b. El CG 25 llega en un momento en que las implicaciones de la ciencia para los derechos humanos son particularmente pertinentes y reciben una gran atención pública, debido a la pandemia del covid-19 y la crisis climática en curso. También es muy relevante para los debates contemporáneos sobre inteligencia artificial y tecnología de vigilancia. El CG 25 aborda estos temas y destaca en todo momento cómo la desigualdad económica socava el disfrute igualitario de los derechos del artículo 15 del PIDESC y cómo el acceso igualitario a la educación científica y a los beneficios del progreso científico puede contribuir a romper el círculo vicioso que genera tal desigualdad ${ }^{123}$. La Sección II de la CG25 identifica y define el contenido normativo, estableciendo el significado del término "progreso científico y sus aplicaciones" y dejando claro que el artículo 15.1.b consagra un "derecho a participar y disfrutar de los beneficios del progreso científico y sus aplicaciones (REBSPA)" "24. En lo que aquí concierne más directamente, la sección V de la CG25 se refiere a "temas especiales de amplia aplicación", entre otros, la relación "compleja" entre REBSPA e investigación científica privada y la propiedad intelectual (PI),

${ }^{122}$ Cabe subrayar la preeminencia del principio de autonomía de voluntad para las partes como rasgo general en el Derecho comparado. A lo sumo, asistimos a algún ejemplo aislado de regulación, a modo de soft law, como sucede en el caso de Australia (Model Access and Benefit Sharing Agreement between Access Provider and Access Party, proposed by the Australian Government, disponible en https:/www.wipo.int/tk/en/databases/contracts/texts/australiamodel.html). La tónica general, no obstante, al menos en la mayoría de los países desarrollados, como EE.UU. o los EE.MM. de la UE, es la ausencia de normas específicas de Derecho internacional privado. En el caso concreto de España, no se contienen normas de este tipo en el Real Decreto 124/2017, de 24 de febrero, relativo al acceso a los recursos genéticos procedentes de taxones silvestres y al control de la utilización (lo que no es de extrañar, puesto que el Reglamento UE que está en su origen tampoco las incluye).

${ }^{123}$ El CG 25 se deriva del CG 17 del Comité, sobre "el derecho de toda persona a beneficiarse de la protección de los intereses morales y materiales resultantes de cualquier producción científica, literaria o artística de la que sea autora”, que se centra también en el mencionado artículo 15.1.b del Pacto, buscando desarrollar una relación más amplia entre la ciencia y los DESC. El Comité se sintió motivado a desarrollar el CG25 por entender que "la ciencia es una de las áreas del Pacto a las que los Estados Partes prestan menos atención en sus informes y diálogos con el Comité".

${ }^{124}$ La Sección III establece los cinco elementos esenciales del derecho: a) "disponibilidad", que "significa que se está produciendo un progreso científico y que los conocimientos científicos y sus aplicaciones están protegidos y ampliamente difundidos"; b) "accesibilidad", que requiere que el progreso científico y sus aplicaciones sean accesibles para todas las personas, sin discriminación; c) "calidad", que requiere que el acceso a las aplicaciones de la ciencia sea "a la ciencia más avanzada, actualizada, generalmente aceptada y verificable disponible en ese momento"; d) "aceptabilidad", que implica que la ciencia debe "difundirse de tal manera que facilite su aceptación en diferentes contextos culturales y sociales"; y e) la protección de la libertad de investigación, que está específicamente protegida por el art. 15.3. En esta sección también se identifican límites aceptables al derecho, como las medidas que buscan "garantizar la seguridad y calidad de los productos utilizados por las personas. La Sección IV establece las obligaciones de los Estados: obligaciones generales, como el deber de "tomar medidas, hasta el máximo de sus recursos disponibles, para la plena realización del derecho", la fuerte presunción de que las medidas regresivas no son permisibles y la obligación inmediata de eliminar todas las formas de discriminación contra individuos y grupos en su disfrute del derecho; también la forma en que "se debe prestar especial atención a ciertos grupos que han experimentado discriminación sistémica en el disfrute del derecho, como mujeres, personas con discapacidad, LGBTI, pueblos indígenas y personas en situación de pobreza". En este sentido, el CG 25 detalla la forma en que "la desigualdad económica obstaculiza el acceso equitativo a la educación científica y a los beneficios del progreso científico para los hogares de bajos ingresos" y pide a los Estados que hagan todos los esfuerzos posibles para romper el "círculo vicioso entre los desigualdad y desigualdad en el acceso al derecho". 
enfatizando que "la gran privatización de la investigación científica sin ninguna otra consideración puede a veces tener efectos negativos en el disfrute del derecho, por ejemplo, sesgando las prioridades de investigación hacia aquellas que son más rentables. También considera el valor instrumental del REBSPA como una "herramienta esencial para la realización de otros DESC, en particular para el derecho a la alimentación y el derecho a la salud". Y reflexiona sobre los riesgos y las promesas de las tecnologías nuevas y emergentes, señalando que, si bien la inteligencia artificial puede generar enormes ganancias productivas, también podría "intensificar las desigualdades sociales al aumentar el desempleo y la segregación en el mercado laboral". Finalmente, el Comité recomienda: a) regulaciones globales para gestionar eficazmente las nuevas tecnologías; b) que las decisiones relativas al desarrollo y uso de estas tecnologías se adopten en un marco de derechos humanos; c) establecer un marco legal que imponga a los actores no estatales un deber de debida diligencia en derechos humanos; y d) regular, de acuerdo con los principios de derechos humanos, la propiedad y el control de los datos ${ }^{125}$.

\section{La protección contra inversiones extranjeras}

32. En el siglo I a.C., comenzó a extenderse una red de vías comerciales desde la ciudad china de Chang'an (actualmente Xi'an) pasando, entre otras, por Karakórum (Mongolia), el Paso de Khunjerab (China/Pakistán), Susa (Persia), el Valle de Fergana (Tayikistán), Samarkanda (Uzbekistán), Taxila (Pakistán), Antioquía (Turquía), Alejandría (Egipto), Kazán (Rusia) y Constantinopla (actualmente Estambul, Turquía) llegando a las puertas de Europa (en el siglo XV, hasta los reinos hispánicos) así como a Somalia y Etiopía, en el África oriental. Tomó su nombre de la mercancía más celebre, producida entonces exclusivamente en China, aunque lo cierto es que monopolizó los principales intercambios comerciales entre Oriente y Occidente durante siglos. Era la "Ruta de la Seda" 126 , que se mantuvo activa durante toda la Edad Media, entrando en declive en el siglo XV debido a la política de bloqueo comercial que practicaba el Imperio otomano (en el extremo occidental de la ruta). La nostalgia por su relevancia histórica ha llevado a muchos países asiáticos a retomar iniciativas de este tipo ${ }^{127}$, aunque la única de estas con una visión y objetivos claros, proyectos de inversión estructurados y planes de implantación es la propuesta oficialmente anunciada (aunque en un primer momento lo fuese con un carácter genérico y más bien de futuro) por el presidente Xi Jinping en el año 2013, durante una visita oficial a Kazajistán. El presidente todavía llevaba solamente un año en el cargo, pero el anuncio supondría el gran proyecto de país durante su mandato, al nivel de la industrialización de Mao y de la apertura comercial de Xiao-

${ }^{125}$ La Sección VI de la CG25 destaca la importancia del deber de cooperar internacionalmente para el cumplimiento de todos los DESC, que se refuerza con una referencia específica a la cooperación internacional dentro del artículo 15.4. Este deber es esencial debido a las desigualdades entre los estados y al hecho de que las amenazas globales como el cambio climático "no se pueden abordar adecuadamente sin una sólida cooperación internacional". También es particularmente relevante para las pandemias, ya que "los virus y otros patógenos no respetan fronteras". En tales contextos, el papel de la OMS se considera que es "fundamental y debe ser apoyado", con el intercambio de los mejores conocimientos científicos "crucial para mitigar el impacto de la enfermedad y acelerar el descubrimiento de tratamientos y vacunas eficaces". Los Estados también tienen obligaciones extraterritoriales, que incluyen "regular y monitorear la conducta de las empresas multinacionales sobre las cuales pueden ejercer control a fin de que estas empresas ejerzan la debida diligencia para respetar la RPEBSPA".

${ }^{126}$ En un primer momento, la ruta se estructura en torno al intercambio de seda entre romanos y chinos, pero las vías comerciales abiertas pronto comienzan a ser aprovechadas para el intercambio de metales preciosos, lana, lino y especias, en cuanto a comercio hacia occidente; mientras que los asiáticos adquirían caballos, plata y distintas manufacturas (C.D. WAUGH, "Richtofen's "Silk Roads": Toward the Archaeology of a Concept", The Silk Road. The Bridge Between Eastern and Western Cultures, vol. 5, 2007, pp. 1-10). El intercambio de mercancías, que alcanza su apogeo en el siglo VIII, durante el gobierno de la dinastía Tang, es tan activo que la inestabilidad en uno de los dos extremos de la ruta podía perjudicar gravemente a los territorios involucrados (D. Lucas Herraiz, "La Ruta de la Seda. Un proyecto de la República Popular China. TFM en Estudios Internacionales: organizaciones internacionales y cooperación”, Colección Memorias MEI, Facultad de Derecho, Universidad de Barcelona, 2017).

${ }^{127}$ Empezando por Japón que, en 1997, renombró su política diplomática económica como "Diplomacia de la Ruta de la Seda"; y siguiendo por Corea del Sur, que estructuró sus relaciones con los países de Asia Central siguiendo precisamente este eje. Asimismo, Moscú puso en marcha en 2015 un proyecto de mercado común entre Rusia, Bielorrusia, Kazajistán, Armenia y Kirguistán (Comisión Económica Euroasiática, 2018). 
ping. Ya en este primer periodo comienza a dotarse a la iniciativa de fuentes de financiación pública específicas (Fondo de la Ruta de la Seda y el Nuevo Banco de Desarrollo) y se crea una comisión específica encargada de su puesta en marcha, liderada por el viceprimer ministro Zhang Gaoli. La Nueva Ruta no supone tanto la creación de una institución multilateral mediante unas normas que unifiquen a todos los países dentro de ella, sino que pretende basarse en acuerdos bilaterales entre los socios. En esta misma línea, el propio gobierno de Pekín insiste en la ausencia de propósitos ideológicos o geopolíticos de la iniciativa. Pero, dejando al margen estos componentes ${ }^{128}$, lo cierto es que la crisis económica de la pasada década demostró la dependencia china de las exportaciones, de modo que, en cuanto la demanda de los países occidentales comenzó a resentirse, el crecimiento del PIB chino también lo hizo. Parece entonces obvio que China necesita dinamizarse para entrar de lleno en las economías de alto desarrollo, si no quiere encontrarse en la situación de algunos países latinoamericanos, por lo que la Nueva Ruta permitiría solucionar una serie de problemas asociados a su estructura económica actual ${ }^{129}$.

33. Asistimos en la actualidad a un cambio de orientación en las inversiones extranjeras, con la irrupción en el escenario global de nuevos actores que han provocado el desplazamiento de inversores tradicionales en la UE. Esto no implica que EE.UU o Japón vayan a desaparecer como inversores, pero el futuro parece tener una mayor presencia naciones emergentes como China, Brasil, Rusia o la India. La UE, como economía moderna y desarrollada, se especializa en sectores y servicios innovadores; y la inversión extranjera suele dirigirse hacia territorios donde se genera mayor valor agregado con menos costes, por lo que los fondos se orientarán a los sectores objeto de mayor especialización en cada país. Por tanto, la UE debe mantener un difícil equilibrio entre la independencia de los sectores clave para su economía y el (importante) flujo de dinero procedente de terceros Estados. Además, cabe recordar que las empresas con mayor necesidad de expansión tienden a crear sucursales, como forma importante de inversión extranjera, pero también como inicio de su penetración en los mercados, que suelen culminar adquiriendo compañías locales, por lo que se corre el riesgo de que las empresas más influyentes de un Estado acaben en manos extranjeras. Cuando esos inversores foráneos son, además, entes públicos (total o parcialmente), existe el peligro añadido de que gobiernos extranjeros invadan políticas de los países receptores, como sucede precisamente con China. De ahí que, a la vista del proyecto chino de expansión económica descrito en el epígrafe anterior, que incluye la posibilidad llevar a cabo fuertes inversiones en diversos países europeos, las alarmas ya han saltado en Bruselas (es decir, en Berlín), dando lugar a la aprobación del Reglamento (UE) 2019/452, del Parlamento Europeo y del Consejo, de 19 de marzo de 2019, en vigor desde el 10 de abril de tal año, para el control de las inversiones extranjeras directas en la Unión ${ }^{130}$. Cerrando el círculo del presente paradójico hipermoderno en que vivimos, coexisten ahora así protección de y contra inversiones extranjeras ${ }^{131}$. Ciertamente, la decisión final en cuanto a la aproba-

${ }^{128}$ Un análisis de la óptica iusinternacionalista de sus conexiones se recoge en el interesante estudio de C. EsPLUGUES MotA, "La creciente interacción entre la seguridad nacional y el comercio internacional: hacia una concreción del significado y alcance del artículo XXI GATT en tiempo de cambios tecnológicos y competencia geopolítica", Cuadernos de Derecho Transnacional, marzo 2020, vol. 12, nº 1, pp. 170-202 (disponible en https://doi.org/10.20318/cdt.2020.5184170).

${ }^{129}$ D. Blasingame, The Middle-Income Trap: Is the One Belt, One Road Initiative Key to China's Ascension to a High-Income Economy?, mayo 2018, disponible en el vínculo siguiente: https://papers.ssrn.com/sol3/papers.cfm?abstract_id=3176047.

${ }^{130}$ Sobre este asunto, vid., por todos, en España, C. Esplugues MотA, El Control de las Inversiones Extranjeras Directas, Tirant lo Blanch, Valencia, 2018; id., "La propuesta de Reglamento estableciendo un marco para la evaluación de las inversiones extranjeras directas en la Unión Europea de septiembre de 2017”, Cuadernos de Derecho Transnacional, marzo de 2018, vol. 10, no 1, pp. 164-195 (https://doi.org/10.20318/cdt.2018.4120); id., "Securitización e inversiones extranjeras: control del riesgo de ciertas inversiones para la seguridad nacional del Estado", Anuario Colombiano de Derecho Internacional, $\mathrm{n}^{\circ} 12$, 2019, pp. 121-156.

${ }^{131}$ En las "Orientaciones dirigidas a los Estados Miembros en relación con las inversiones extranjeras directas y la libre circulación de capitales de terceros países, así como la protección de los activos estratégicos de Europa, antes de la aplicación del Reglamento (UE) 2019/452 (Reglamento para el control de las inversiones extranjeras directas)" publicadas como Comunicación de la Comisión el 26 de marzo de 2020 (las "Orientaciones sobre IED de 26/03/2020"), se llama a los EE. MM. a: 1) "utilizar plenamente desde ahora sus mecanismos de control de las IED [(actualmente en 14 países)] con el fin de tener plenamente en cuenta los riesgos para las infraestructuras sanitarias esenciales, el suministro de insumos fundamentales y otros sectores críticos, como se prevé en el marco jurídico de la UE"; y 2) "en el caso de aquellos Estados miembros que actualmente no disponen de un mecanismo de control, o cuyos mecanismos de control no cubren todas las operaciones pertinentes, 
ción, restricción o prohibición de las mismas se mantiene como competencia de los EE. MM., según la legislación de cada uno. Ahora bien, el Reglamento dispone los requisitos mínimos que se deben cumplir para adoptar un mecanismo de control de inversiones extranjeras ${ }^{132}$ y enumera una lista de factores que pueden considerarse para determinar si una medida puede afectar al orden o a la seguridad pública y justificar, por tanto, el recurso a esta técnica ${ }^{133}$. Se establece asimismo la obligación para el E. M. que reciba la inversión de poner a disposición de la Comisión Europea o de otros E.M. información concreta sobre el inversor y su proyecto, así como una serie de mecanismos de cooperación: a) en relación con inversiones extranjeras que estén siendo objeto de control; b) en relación con inversiones extranjeras que no estén siendo objeto de control; y c) en caso de inversiones extranjeras que puedan afectar a proyectos o programas de interés para la Unión.

34. No cabe cerrar este trabajo sin volver de nuevo sobre el fenómeno estrella del año 2020, primera página diaria desde hace meses en todos los medios de comunicación nacionales e internacionales y que sin duda pasará a los anales de la Historia contemporánea como una pesadilla distópica colectiva. Consecuencia o no de la hipermodernidad, el impacto de una pandemia mundial como la vivida, incluyendo un confinamiento forzoso de la población durante varias semanas en numerosos países del mundo y en prácticamente toda la UE (con la sola excepción inicial de Suecia y poco más), impregna todos los sectores y ámbitos de la sociedad, también el jurídico y, por extensión, al Derecho internacional privado ${ }^{134}$. Una muestra se percibe, precisamente, en la regulación española frente a las inversiones extranjeras. El Real Decreto-Ley 8/2020, del 17 de marzo ${ }^{135}$, adopta medidas urgentes y extraordinarias para mitigar el impacto socio-económico del brote pandémico de la COVID-19 en España ${ }^{136}$. Ante tal contexto, y para responder a la actual situación, se han tomado medidas adicionales respecto de determinadas inversiones extranjeras directas en España. Más concretamente, se establece la suspensión del régimen de liberalización para ciertas inversiones extranjeras directas en determinados sectores estratégicos de la economía española y que afectan a la seguridad nacional, al orden público y a la salud pública. Así, tomando como modelo el Reglamento (UE) 2019/452, tras definir lo que se entiende por tales sectores estratégicos y las condiciones subjetivas del inversor, se establece como condición previa que las inversiones concernidas estarán sujetas a autorización administrativa previa otorgada por el Gobierno de España (Consejo de Ministros) de acuerdo con las condiciones establecidas por la autoridad

que establezcan un mecanismo de control completo y, mientras tanto, que utilicen todas las demás opciones disponibles para abordar los casos en los que la adquisición o el control de una determinada empresa, infraestructura o tecnología pueda suponer un riesgo para la seguridad o el orden público en la UE, incluido un riesgo para las infraestructuras sanitarias esenciales y el suministro de insumos críticos".

132 a) Las normas y procedimientos relacionados con los mecanismos de control así como los plazos aplicables serán transparentes y no discriminarán entre terceros países. b) Los EE.MM. aplicarán plazos en el marco de sus mecanismos de control, a cuyo término se dictará resolución expresa. c) Se protegerá la información confidencial facilitada al E.M. que esté efectuando el control. d) Se deberá establecer un sistema de recursos contra las decisiones adoptadas bajo esta normativa.

${ }^{133}$ El Reglamento distingue entre los factores a considerar por razón del sector afectado por la inversión (I) y los atribuibles al inversor extranjero (II). En (I) destacan: a) Las infraestructuras críticas, tanto físicas como virtuales, incluyendo las infraestructuras de energía, transporte, agua, sanidad, comunicaciones, medios de comunicación, tratamiento o almacenamiento de datos, aeroespacial, de defensa, electoral o financiera y las instalaciones sensibles; b) Tecnologías críticas y productos de doble uso, incluidas la inteligencia artificial, la robótica, los semicondutores, la ciberseguridad, las tecnologías aeroespacial de defensa, de almacenamiento de energía, cuántica y nuclear, así como las nanotecnologías y biotecnologías; c) El suministro de insumos fundamentales, en particular energía o materias primas, así como la seguridad alimentaria; d) El acceso a información sensible, en particular, datos personales, o la capacidad de control de dicha información; e) Pluralismo y libertad de los medios de comunicación. Por su parte, en (II) se encuentran: a) Si el inversor extranjero está controlado directa o indirectamente por el Gobierno de un tercer país, mediante la estructura de propiedad o una financiación significativa; b) Si el inversor extranjero ha participado en actividades que puedan afectar a la seguridad o el orden público de un E.M.; c) Si existe un riesgo grave de que el inversor realice actividades delictivas o ilegales.

${ }^{134}$ Véase un claro ejemplo en el trabajo de G. Palao Moreno, "Protección del consumidor internacional en tiempos de COVID-19”, Actualidad Jurídica Iberoamericana, no 12 bis, mayo 2020, pp. 624-633 (http://www.revista-aji.com/wp-content/ uploads/2020/05/58._Guillermo_Palao_pp._624-633.pdf).

${ }^{135}$ BOE de 18 de marzo, modificado y complementado por el Real-Decreto Ley 11/2020, de 31 de marzo (BOE de 1 de abril).

${ }^{136}$ Sobre este asunto ha reflexionado recientemente C.A. Esplugues Mota, en "Adiós a la libre circulación de inversiones ¿sólo en tiempos de coronavirus?”, Actualidad Jurídica Iberoamericana, no 12 bis, mayo 2020, pp. 614-623. 
administrativa competente (es decir, el regulador del sector estratégico afectado). Una vez la solicitud de autorización se ha presentado, el Consejo de Ministros será el único órgano competente para conceder o denegar la autorización. La ausencia de resolución favorable a la autorización en el plazo de seis meses se entenderá como una denegación de la misma (por silencio administrativo negativo, según el artículo 6 de la Ley 19/2003, de 4 de julio, en conexión con el 24.1 ${ }^{\circ}$ de la Ley 39/2015, de 1 de octubre). No obstante, la DT $2^{\text {a }}$ del R.D.-Ley 11/2020 establece transitoriamente un procedimiento simplificado (con un plazo de 30 días para otorgar o denegar la autorización) para autorizaciones de concretas inversiones, quedando además en todo caso exentas de autorización las que tengan un valor inferior a un millón de euros. Las operaciones de inversión llevadas a cabo sin la preceptiva autorización previa carecerán de validez y efectos jurídicos, en tanto no se produzca su legalización de acuerdo con lo establecido en el artículo 6 de la citada Ley 19/2003.

\section{Conclusiones}

35. La nueva década se abre en una compleja coyuntura a nivel económico y social, también en el entorno transfronterizo, planteando novedosos retos para el Derecho internacional privado, particularmente en el ámbito comercial, pero no únicamente. Así, en el sector del Derecho de la persona y de la familia, nos encontramos ante el nacimiento de un tertium genus, la "personalidad electrónica", a partir de los avances de la inteligencia artificial, donde la sujeción al país de origen, a modo de un estatuto personal, puede erigirse como solución en el marco del mercado interno europeo. En materia de personas jurídicas, la apuesta por las herramientas digitales para agilizar su actividad económica en operaciones transfronterizas, así como facilitar la obtención y circulación de información relevante, contribuye a fortalecer la libertad de establecimiento; todo ello conduce a la necesidad de examinar un amplio conjunto de cuestiones relativas a la conjugación de los procesos de digitalización con las normas de transparencia en el ámbito societario, como son, por ejemplo, la interconexión de los registros, en las sociedades cerradas, o el voto robotizado, en las cotizadas. Por otra parte, en el campo del Derecho de familia, las nuevas y variadas posibilidades de unión han desembocado también, junto con los adelantos médicos, en una diferente concepción de la filiación, mediante la figura de la gestación subrogada, con importantes derivaciones en el plano transfronterizo, destacando aquí la labor de la Conferencia de la Haya de Derecho internacional privado y, como problema, la cuestión relativa al reconocimiento de menores nacidos en el extranjero mediante dicha técnica, lo que dependerá de presencia o no de una resolución judicial en origen sobre la filiación.

36. En el marco de la sociedad de la (hiper)información asistimos a un incremento exponencial de la transmisión de datos personales, conducente a la necesidad de articular unas vías de protección adecuadas en el ámbito transfronterizo; algo que, al menos en el contexto de las relaciones UE-EE.UU., se ha revelado como un asunto altamente espinoso, tras el reciente pronunciamiento al respecto del TJUE que ha dado al traste con el acuerdo bilateral conocido como Privacy-Shield, cuyas consecuencias están todavía por ver, pero que, por el momento, supone la ilegalidad de las transmisiones de datos entre empresas de ambos territorios. En el sector del consumo, la posibilidad de bloquear el acceso a determinados productos o servicios ofrecidos en línea dependiendo del origen geográfico del consumidor, considerado como práctica contraria al pleno potencial del mercado interior, ha sido limitada a través de una normativa específica, con consecuencias directas sobre la interpretación de normas clásicas del Derecho internacional privado de la UE, como el Reglamento Bruselas I bis o el Roma I. Finalmente, el siglo XXI ha alumbrado también un nuevo modelo de negocio, conocido con carácter general como "economía de plataforma", que permite llevar a cabo transacciones de la más diversa índole en materia de bienes y servicios poniendo en contacto a dos partes contractuales que pueden hallarse en Estados diferentes. En dicho entorno, cobran especial relevancia actualmente los mecanismos reputacionales como guía para la autorregulación de tales plataformas, dando lugar a un nuevo modelo normativo que puede considerarse incluso un cambio de paradigma, a través de la generación de nuevas reglas que, 
desde el punto de vista más audaz, permitiría una autorregulación espontánea de abajo arriba, partiendo de las calificaciones de los usuarios de dichas plataformas.

37. El tercero de los sectores explorados se acerca, desde una perspectiva más procesal, al terreno de la justicia civil transfronteriza, abordando así, en primer lugar, la situación de los medios alternativos de resolución de conflictos, en general, y centrándose en las disputas de consumo, en particular; entorno en el que existe una plataforma de la UE a tal fin, para facilitar la resolución extrajudicial de este tipo de conflictos de forma trasparente, eficaz, independiente, imparcial y equitativa. A continuación, se trata la situación de las acciones colectivas dentro del Derecho procesal civil internacional de la UE, donde existe actualmente la reciente Directiva (UE) 202/1828, con la pretensión de que puedan abarcar un núcleo de supuestos mayores, así como para favorecer los acuerdos colectivos extrajudiciales. En último lugar, se expone la situación en la que se hayan los trabajos de la UE relativos a la reforma del Reglamento 1393/2007, sobre notificación y traslado de documentos, que se está adecuando a los últimos avances en materia de administración electrónica, confiando en poder agilizar y simplificar los procesos judiciales transfronterizos, así como aumentar la previsibilidad del procedimiento, incrementando con todo ello la seguridad jurídica.

38. El último bloque de problemas analizado se refiere a un conjunto de situaciones a caballo entre el Derecho público y el privado, que dan lugar, en el ámbito internacional, a un híbrido normativo de técnicas que presentan como objetivo común la protección de una serie de intereses colectivos con un fuerte componente estatal. El primero de los sectores trata sobre los bienes culturales, donde el último paso se ha dado mediante el Reglamento 2019/880, que establece un sistema de licencias de importación o de declaración del importador, dependiendo del tipo de bien, con el fin de garantizar controles uniformes en la Unión para la importación de bienes culturales. En segundo lugar, se aborda la protección internacional de los recursos genéticos, donde el problema fundamental consiste en conjugar adecuadamente los intereses contrapuestos en relación con el derecho de acceso al recurso y el reparto de beneficios, centrándose los problemas de Derecho internacional privado sobre todos en los necesarios acuerdos entre las partes interesadas, dependiendo del modelo legal o puramente contractual que se siga en cada Estado. Finalmente, por lo que respecta al tercer caso expuesto -las inversiones extranjeras- desde la tradicional protección del inversor nacional en el extranjero, como consecuencia de los cambios señalados al principio de este trabajo, asistimos a un cambio hacia la protección contra concretos inversores extranjeros; lo que ha cristalizado en una normativa específica en el marco de la UE, ya incorporada al ordenamiento español, destinada a suspender el régimen de liberalización de determinadas inversiones en sectores estratégicos.

39. Como conclusión global, derivada del conjunto de fenómenos expuesto, cabe señalar que el espectro de las relaciones jurídico-privadas transfronterizas se ha ido transformando a lo largo del siglo XXI, abriéndose hacia un abanico de supuestos donde se aprecian novedades no solo por razón de su objeto, como puede ser más habitual, sino incluso en relación con la propia naturaleza de los sujetos intervinientes o el entorno donde las mismas se desenvuelven, como resultado de los exponenciales avances acaecidos en materia de tecnología. Asimismo, las sucesivas crisis económicas vividas a lo largo de las últimas dos décadas, culminadas con la actual pandemia de la COVID-19, han conducido a un escenario de desglobalización, que viene acompañada de una recuperación de la intervención del Estado en las relaciones privadas, todo ello en el marco de una ética colectiva gobernada por los postulados del desarrollo sostenible. Como consecuencia del panorama descrito nos hallamos ante un Derecho internacional privado hiperespecializado, mutante, más fluido o, -en el calificativo acuñado por ZYGMUT BAUMAN para referirse a la nueva modernidad- "líquido", en la evolución que se aprecia desde el precedente, más "sólido" -entendido como estable o repetitivo-, hacia un sistema más flexible o voluble, asociado a la desaparición de los referentes. En suma, un Derecho internacional privado propio de los tiempos hipermodernos, según la expresión propuesta en su día por GILLES LiPOVETSKY, en que nos toca vivir. 